\title{
OBTENÇÃO DE UM LEITE DE SOJA DE QUALIDADE ATRAVÉS DO TRATAMENTO DOS GRÃOS EM FORNO DE MICROONDAS
}

\author{
Giovana de Barros Sacco
}

Nutricionista

Orientadora: Prof ${ }^{\text {a }}$ Dr Marisa Ap. B. Regitano d'Arce

Dissertação apresentada à Escola Superior de Agricultura "Luiz de Queiroz", Universidade de São Paulo, para obtenção do título de Mestre em Ciências, Área de Concentração: Ciência e Tecnologia de Alimentos.

Piracicaba

Estado de São Paulo-Brasil

Julho - 2001 


\title{
Dados Internacionais de Catalogação na Publicação (CIP) DIVISĀO DE BIBLIOTECA E DOCUMENTAÇĀO - Campus "Luiz de Queiroz"/USP
}

\author{
Sacco, Giovana de Barros \\ Obtenção de um leite de soja de qualidade através do tratamento dos grãos em \\ formo de microondas / Giovana de Barros Sacco. - - Piracicaba, 2001. \\ 53 p. : il. \\ Dissertação (mestrado) - - Escola Superior de Agricultura Luiz de Queiroz, 2001. \\ Bibliografia. \\ 1. Análise sensorial 2. Leite de soja 3. Microondas 4. Tratamento de semente I. \\ Titulo
}

CDD 664.726

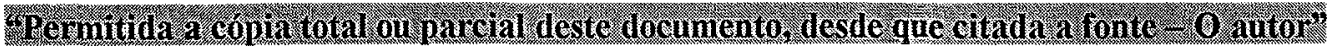




\section{AGRADECIMENTOS}

A Deus por ter me dado fé e determinação;

A meus pais pelo amor e compreensão;

Ao Luiz Antonio, Cristina, Carolina e Hugo, pelo incentivo nas horas de dificuldades;

Ao Carlos, pela paciência e apoio demonstrado nos momentos de dúvida;

À minha orientadora Marisa A. B. Regitano D'Arce, pelo incentivo, amizade e dedicação durante a realização do curso;

À Marta Helena Fillet Spoto pela colaboração, amizade e apoio na análise sensorial;

Aos funcionários do Departamento de Agroindústria, Alimentos e Nutrição especialmente à técnica do Laboratório, Maria Fernanda de Almeida Prado;

A todos os participantes da Análise Sensorial;

À Beatriz, Eliana e Mídiam;

À Lílian M. Pino pelas análises e amizade;

Às "meninas da república";

E a todos que contribuíram, direta ou indiretamente, para a execução deste trabalho. 
Certeza

De tudo ficaram 3 coisas...

A certeza de que estamos começando.

A certeza de que é preciso continuar,

A certeza de que seremos interrompidos antes de terminar...

Façamos da interrupção um caminho novo...

Da queda, um passo de dança...

Do medo, uma escada...

Do sonho, uma ponte...

Da procura, um encontro.

Fernando Sabino 


\section{SUMÁRIO}

Página

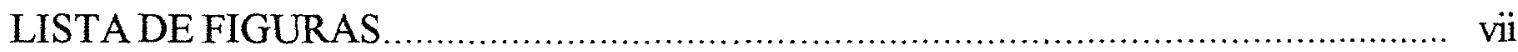

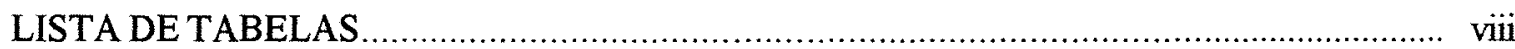

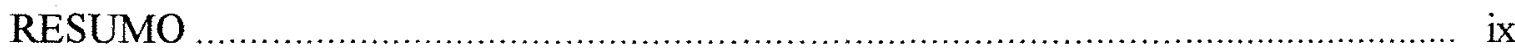

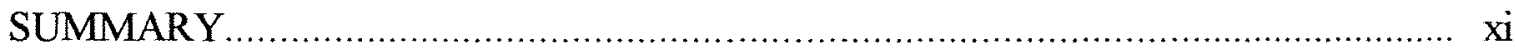

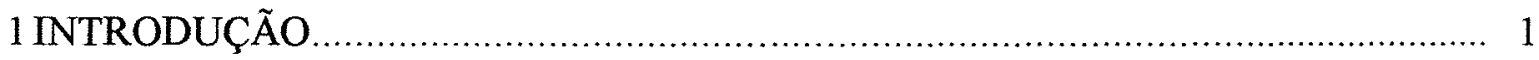

2 REVISÃO DE LITERATURA................................................................ 4

2.1 Produção de soja................................................................................. 4

2.2 Qualidade nutricional da proteína da soja................................................ 4

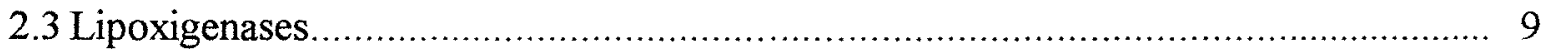

2.4 Condições para atuação das lipoxigenases.............................................. 10

2.5 Processos existentes para a produção de leite de soja.............. 12

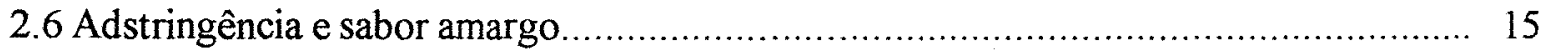

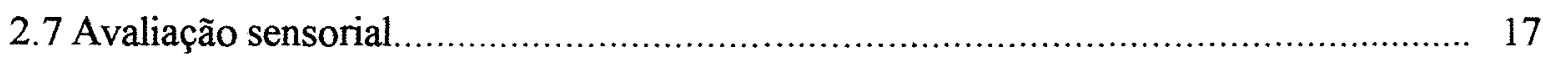

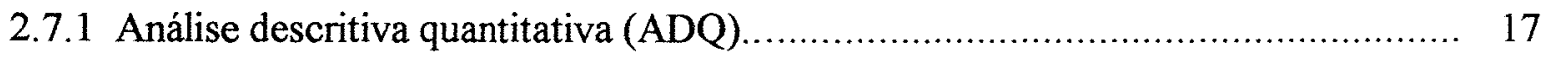

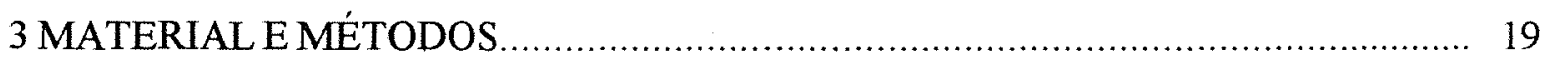

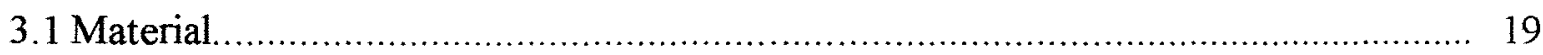

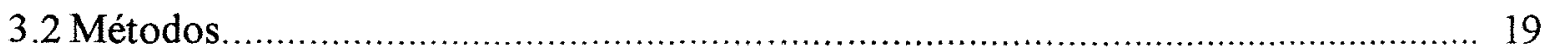


3.2.1 Produção do leite de soja

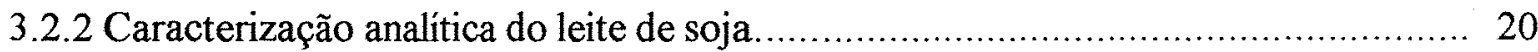

3.2.3 Determinação da atividade de urease ........................................................... 20

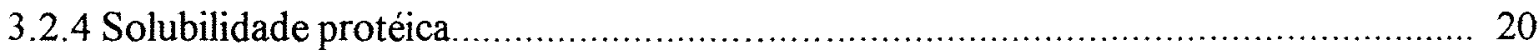

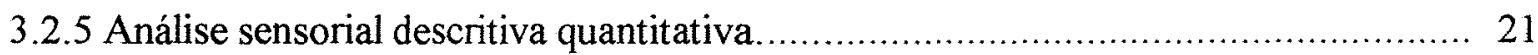

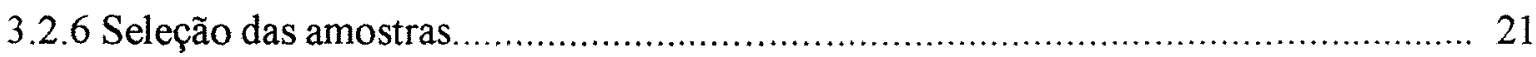

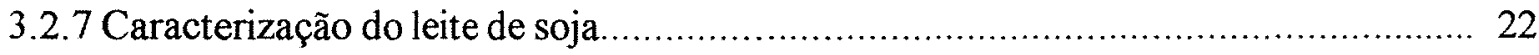

3.2.8 Recrutamento e seleção de equipe de provadores......................................... 23

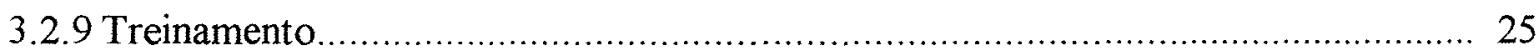

3.2.10 Desenvolvimento de terminologia descritiva ........................................... 26

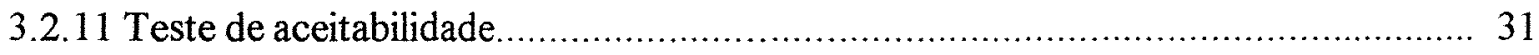

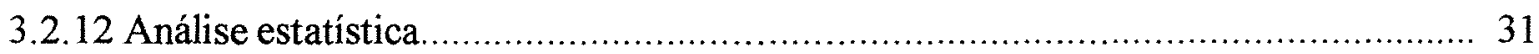

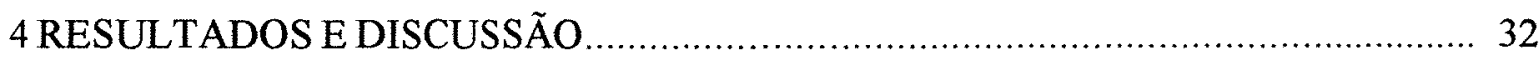

4.1 Características do estrato hidrossolúvel de soja .......................................... 32

4.1.1 Composição química do extrato hidrossolúvel de soja................................... 32

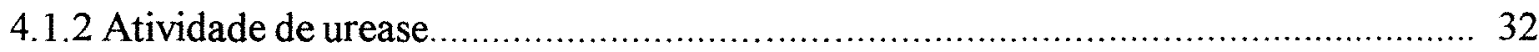

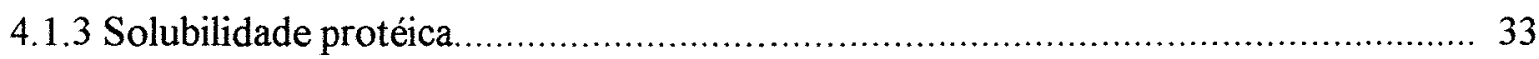

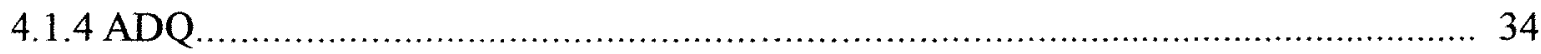

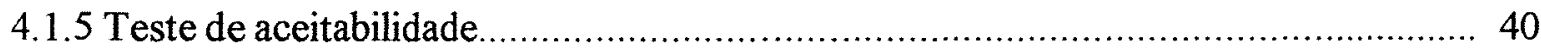

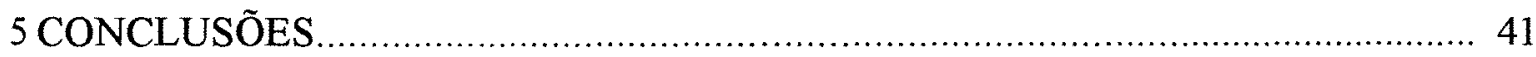

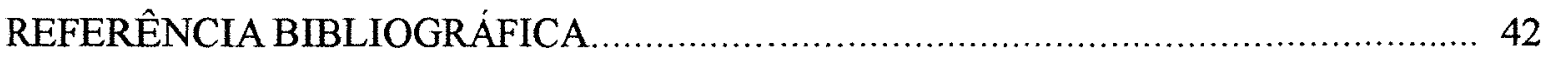




\section{LISTA DE FIGURAS}

Página

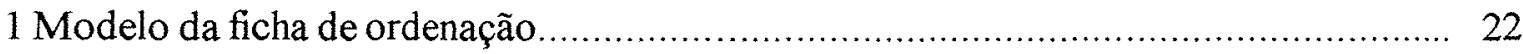

2 Modelo da ficha de identificação dos gostos básicos.......................................... 24

3 Modelo da ficha do Teste Triangular) ......................................................... 25

4 Termos descritivos obtidos pela técnica do perfil livre em amostras de extrato

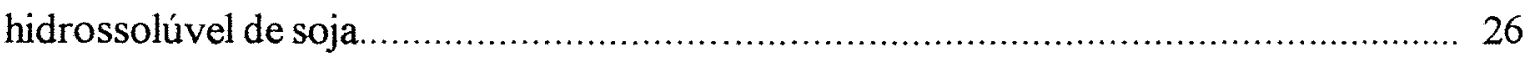

5 Grupos de atributos relacionados pelos provadores, para o perfil de aroma, sabor, aparência e textura do leite de soja submetido a diferentes tratamentos.................... 27 6 Lista de definições dos termos descritivos para os atributos de aroma, sabor, aparência e textura do extrato hidrossolúvel de soja............................................................... 28 7 Ficha de Análise Descritiva Quantitativa do extrato hidrossolúvel de soja............ 30

8 Ficha da Escala Hedônica do extrato hidrossolúvel se soja................................... 31 9 Atributos de aparência e textura organolética do extrato hidrossolúvel de soja submetido a diferentes tratamentos..................................................................... 35 10 Atributos de aroma e sabor do extrato hidrossolúvel de soja submetido a diferentes tratamentos. 39 
LISTA DE TABELAS

Página

1 Métodos de obtenção do leite de soja............................................................... 13

2 Composição química dos extratos hidrossolúveis de soja................................... 32

3 Atividade ureática em soja submetida a diferentes tempos de exposição ao

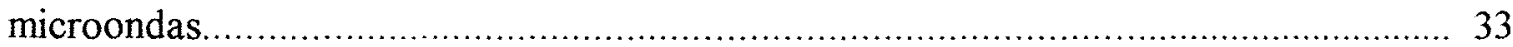

4 Solubilidade protéica residual (\%) dos grãos aquecidos em microondas................. 33

5 Médias referentes aos atributos de aparência e textura organolética do extrato hidrossolúvel de soja submetido a diferentes tratamentos.................................... 34

6 Médias referentes aos atributos de aroma e sabor do extrato hidrossolúvel de soja

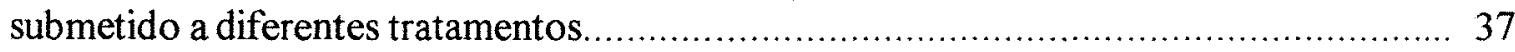

5 Médias de notas do teste de aceitabilidade para o extrato hidrossolúvel de soja submetidos a diferentes tratamentos. 


\section{OBTENÇÃO DE UM LEITE DE SOJA DE QUALIDADE ATRAVÉS DO TRATAMENTO DOS GRÃOS EM FORNO DE MICROONDAS}

Orientadora: Prof ${ }^{a}$. Dr ${ }^{a}$. MARISA APARECIDA BISMARA REGITANO-D'ARCE

\section{RESUMO}

Neste trabalho estudou-se a utilização do microondas como forma de prétratamento térmico da soja, visando a obtenção do extrato hidrossolúvel (leite) de boa aceitabilidade e palatabilidade.

O leite é uma solução coloidal obtida a partir da extração aquosa resultante da hidratação dos grãos de soja convenientemente limpos. É um produto de fácil elaboração, contudo sua utilização na alimentação humana no Brasil é limitada. O fato pode ser justificado por falta de hábito de consumo e problemas ligados ao sabor de feijão cru causado pela atividade da lipoxigenase durante o rompimento e hidratação do grão da soja. Em alguns casos, os preconceitos contra a soja são conseqüências do preparo incorreto de alguns produtos, sem aplicação de tecnologia adequada.

Amostras de 150 gramas de grãos foram aquecidas em forno de microondas por tempos de 140 e 150 segundos e o leite preparado para comparação sensorial com o preparado pelo método Illinois. As características organoléticas do produto final foram estudadas, considerando os fatores que mais restringem a aceitação deste produto. 
Para se verificar a aceitabilidade dos diferentes tratamentos, foi realizado o teste hedônico de 9 pontos, variando de gostei extremamente (9) e desgostei extremamente (1). A cor mais acentuada, menor viscosidade, e o sabor de tostado foram encontrados nos leites de soja aquecida em forno de microondas. Ambos os leites preparados com a soja tratada em microondas apresentaram-se sensorialmente aceitáveis e o teste aplicado mostrou-se eficaz ao compará-los com o obtido através do método Illinois. $\mathrm{O}$ tratamento foi capaz de inativar os compostos antinutricionais cuja atividade foi verificada através da enzima urease, garantindo sabor adequado e ausência de antinutricionais. 


\title{
SOYMILK PRODUCTION FROM MICROWAVED BEANS
}

\author{
Author: Giovana de Barros Sacco \\ Adviser: Prof ${ }^{a}$. Dr ${ }^{a}$. MARISA APARECIDA BISMARA REGITANO-D'ARCE
}

\section{SUMMARY}

Microwaves were rered as a thermal treatment for soybeans, aiming at the obtention of a hydrossoluble extract one of good acceptability and palability.

Soymilk is a coloidal solution obtained from an aqueous extraction after hydration of adequately cleaned beans.

It is easily produced, however its use human foods is limited in Brazil. This may be explained by a lack of habit of consumption, but also by problems related to the beany flavor caused by lipoxigenase activity during soybeans grinding and soaking. In some cases the prejudices against soybeans are consequences of incorrect preparation of some products, without proper tecnology.

Samples of 150 grams of soybeans were heated in a microwave oven for 140 and 150 seconds and the milk was prepared for sensorial comparison with the one prepared according to the Illinois method. Organoleptical characteristics of the final product were studied, considering the factors that restrict product acceptance. 
In order to ckeck acceptability of the different treatments a nine point hedonic scale (from "I liked extremely" and "I disliked extremely") was evalueded. The strongest color the less viscous and a toasted flavor were characteristics found in soymilks from beans heated in microwave ovens. Both of these were considered sensorially acceptable and the test applied was efficient in comparing them to the Illinois.

Microwaving was able to inactivate antinutritionals whose activity was checked through urease enzyme guaranteeing adequate flavor and antinutritionals inactivation confirmed. 


\section{INTRODUÇÃo}

A nutrição desempenha uma função significativa na prevenção de doenças e na manutenção da saúde, sendo, portanto, um dos fatores fundamentais para o desenvolvimento dos povos (Branco, 1988).

Estudos mostram que a desnutrição é um dos maiores problemas encontrados nos países em desenvolvimento. Dentre as diversas fontes protéicas de origem vegetal, a soja representa uma das melhores alternativas para minimizar tal problema, pois oferece proteína de alto valor biológico. No Brasil, os hábitos alimentares constituem o principal fator limitante à ampla aceitação de produtos contendo soja (Costa de Mello et al., 1996).

O leite é uma solução coloidal, obtida a partir da extração aquosa resultante da hidratação dos grãos de soja, convenientemente limpos, seguido de processamento tecnológico adequado. É um produto de fácil elaboração, sendo sua utilização limitada na alimentação humana, no Brasil. O fato pode ser justificado por falta de hábito de consumo e problemas ligados ao sabor de feijão cru ("beany flavor"), causado pela atividade da lipoxigenase durante o rompimento e hidratação dos grãos da soja. Em alguns casos, os preconceitos contra a soja são conseqüências do preparo incorreto de alguns produtos, sem aplicação de tecnologia adequada (Silva Junior, 1997).

Vários estudos têm sido realizados no intuito de eliminar ou, pelo menos, de atenuar o efeito das substâncias responsáveis pelo sabor característico da soja. Eles são produzidos por enzimas lipoxigenases que, quando ativadas durante a maceração ou na presença de umidade, oxidam os ácidos graxos e produzem compostos voláteis de odor desagradável (Cowan, 1973). Essas enzimas podem ser inativadas por tratamento térmico que pode incluir, desde um branqueamento até a um aquecimento em forno de 
microondas. Um dos tratamentos mais utilizados, considerado tradicional para a atenuação do sabor desagradável é o processo Illinois (Nelson et al., 1976), cujo resultado obtido agrada o paladar dos provadores.

O consumo da soja também é limitado pela presença de fatores antinutricionais, como inibidores de proteases e lectinas ou fitohemaglutininas, os quais não permitem o consumo dos grãos sem que haja algum tipo de tratamento que promova sua inativação (Solorzano, et al., 1997).

Evangelista e Regitano-d'Arce (1999) verificaram, de forma indireta, que o aquecimento por microondas consegue prevenir a atividade da lipoxigenase durante a maceração. Além disso, o tratamento no forno de microondas é capaz de inativar os compostos antinutricionais, os quais podem ser acompanhados pela enzima urease, cuja atividade pode ser usada como índice para verificar a destruição dos inibidores de tripsina e hemaglutininas (Pino \& Regitano-d'Arce, 2000). Portanto, se a urease estiver inativada após um tratamento, pode-se considerá-la igualmente inativa, pois sua resistência térmica é equivalente à desses princípios antinutricionais.

O leite, obtido de grãos tratados sob condições de tempo e temperatura adequados em forno de microondas, deve garantir um sabor agradável, aliado à ausência de antinutricionais.

Além do leite, que é uma fonte bastante rica em nutrientes e de fácil preparo, existe uma diversidade muito grande de alimentos à base de soja, como por exemplo, os produtos tradicionais: tofu, farelo e farinha. $\mathrm{O}$ extrato hidrossolúvel de soja constitui um produto em ascensão no mercado nacional, onde novas marcas têm sido lançadas (Gomes et al., 1995). Devido ao aumento da tecnologia gerada por pesquisas, como a melhora do seu "flavor", a preocupação com o colesterol e outros problemas de saúde, como o câncer, está fazendo com que o consumo desse produto aumente (Haumann, 1984). Portanto, o leite de soja pode ser adicionado à alimentação da população, devido ao seu baixo custo e diversidade de produtos possíveis de serem obtidos. Sua importância torna-se ainda mais evidente, uma vez que pode ser usado por pessoas intolerantes à lactose ou às proteínas presentes no leite bovino.

Este trabalho tem como objetivo a definição dos parâmetros de aquecimento de 
grãos de soja em forno de microondas para inativação de antinutricionais e lipoxigenase com vistas à obtenção de um leite de soja de qualidade, bem como à definição do processamento desses grãos a leite. O leite obtido foi analisado, sensorialmente, comparando com o obtido por um processo clássico, como o de Illinois.

A análise sensorial, é considerada uma disciplina científica, utilizada para evocar, medir, analisar e interpretar reações produzidas pelas características de qualidade dos alimentos, de como são percebidas pelos sentidos da visão, olfato, paladar (gosto), tato e audição (Amerine et al.,1965).

Nos atuais estudos objetivos e subjetivos do sabor, muitas técnicas de avaliação têm se direcionado aos métodos sensoriais, destinados a eliminar as preferências pessoais nas avaliações, sendo a análise descritiva a mais sofisticada das metodologias de avaliação sensorial. 


\section{REVISÃO DE LITERATURA}

\subsection{Produção de soja}

A soja é cultivada em muitos países, principalmente na China, Estados Unidos e Brasil.

Em 1880, foi levada para os Estados Unidos e ali empregada como ração animal até que, após campanha desenvolvida pelo Departamento Agrícola daquele país, a soja passou a ser usada para fins industriais.

A cultura da soja (Glycine max (L) Merrill) tem sido amplamente estudada e melhorada, desde sua introdução no Brasil, em 1882, no estado da Bahia (Câmara et al., 1997) e devido ao sucesso conseguido espalhou-se pelo país inteiro, como matériaprima para a indústria de óleos comestíveis. A cultura da soja em nosso país tem demonstrado notável expansão principalmente nos estados de Goiás e Mato Grosso, transformando-se rapidamente num dos principais produtos da economia agrícola nacional.

\subsection{Qualidade nutricional da proteína da soja}

Sabe-se que a soja representa uma das melhores fontes vegetais calóriooprotéicas, contendo cerca de $40 \%$ de proteína de boa qualidade e $20 \%$ de óleo (Vieira, 1997). O leite de soja, por ser uma bebida protéica de baixo custo, de bom valor nutritivo e de fácil obtenção, representa, sem dúvida, importante alternativa para a nutrição humana, particularmente onde o leite de vaca é caro ou não é disponivel (Cabral et al, 1997). 
A proteína de soja tem um bom valor nutritivo quando é adequadamente processada, de maneira que destrua o fator antinutricional, evitando a perda de aminoácidos essenciais. Dentre os aminoácidos, somente a cistina sofre uma substancial diminuição como resultado de cozimento, provavelmente por degradação térmica (Cabral et al., 1995).

$O$ alto teor de proteína faz dessa leguminosa, matéria-prima para obtenção de vários derivados protéicos, dentre os quais podem ser ressaltados a farinha (integral e desengordurada), os isolados e concentrados protéicos, proteína vegetal texturizada e os extratos hidrossolúveis, líquido e em pó (Aminlari, 1997).

Gordon (1970) estudou a composição de aminoácidos essenciais presentes na soja e confirmou a metionina e a cistina como limitantes .

Coppock (1974) observou que os teores de metionina encontrados na farinha de soja desengordurada eram menores que os encontrados na farinha de trigo e proteína de ovo, como era de se esperar em leguminosas.

A desnutrição é um dos problemas mais graves encontrados nos países em desenvolvimento. A soja representa uma das melhores alternativas para minimizar tal problema, pois constitui-se uma importante fonte de proteínas, sais minerais e vitaminas. Entretanto apresenta sabores indesejáveis em relação aos padrões de paladar ocidental (Paula et al., 1995).

A desnutrição é o estado patológico, originado do consumo deficiente ou inadequado de nutrientes, durante um período prolongado. Manifesta-se por alterações fisicas (peso e estatura), psicológicas e bioquímicas (Chaves, 1978). Compromete o futuro de um país, reduzindo e danificando sua maior fonte de riquezas, representada pelos seus recursos humanos.

Um dos grandes problemas do mundo atual consiste na dificuldade de suprir as necessidades protéicas das populações de baixa renda e por ser uma bebida protéica de baixo custo, de bom valor nutritivo e de fácil obtenção, representa, sem dúvida, importante alternativa para a nutrição humana em geral, particularmente nos lugares onde o leite bovino é caro e não disponível (Buchanan \& Stewart, 1977; Cabral et al., 1997; Teixeira et al., 1995). 
A importância econômica da soja deve-se ao fato de ela se constituir uma fonte considerável de óleo e proteína, apresentando grande diversidade de usos, tanto agrícola como industrial.

Estudos dos últimos 25 anos, têm comprovado as propriedades fitoterapêticas da soja como anticancerigena, além de reduzir a taxa de colesterol, amenizar problemas da menopausa, prevenir doenças coronárias, entre outras (Bernard, 1999; Gorman, 1999).

A FDA (Food and Drug Administration) recomenda o consumo diário de $25 \mathrm{~g}$ de proteína de soja, além da mudança de hábito alimentar, de modo a obter os beneficios da soja, citados anteriormente. Apesar de possuir todas essas características, sem esquecer o seu alto valor protéico, o consumo da soja pelos ocidentais ainda é bastante reduzido, em comparação ao dos orientais.

O extrato protéico solúvel, extraído do grão da soja, comumente conhecido como leite de soja, é um produto de alto valor nutritivo e de fácil elaboração. É uma solução coloidal obtida a partir da extração aquosa resultante da hidratação dos grãos de soja, convenientemente limpos, seguido de processamento tecnológico adequado, adicionado ou não de ingredientes opcionais permitidos, podendo ser submetido à desidratação total ou parcial (Tang et al., 1997; Regitano-d'Arce, 1982). Tem alcançado grande destaque na alimentação de crianças e adultos, particularmente dos que apresentam intolerância ao leite de vaca, causada por falhas genéticas na digestão da lactose, ou por reações alérgicas às suas proteínas. Também é recomendado para diabéticos pelo seu baixo teor de carboidratos. Além disso, não contém colesterol, sendo também fonte de ácidos graxos insaturados e de lecitina.

A utilização da soja na alimentação humana, no Brasil, é limitada. O fato pode ser justificado por falta de hábito de consumo, problemas ligados ao sabor de feijão cru ("beany flavor"), causado pela atividade da lipoxigenase durante o rompimento e hidratação do grão de soja, propriedades antinutricionais e efeitos físiológicos a eles atribuídos (Gomes et al., 1989; Cabral et al., 1997; Rackins et al., 1979).

Além da deficiência em aminoácidos sulfurados, a soja, crua, apresenta substâncias que, atuando de maneira inter-relacionada, são responsáveis por diferentes respostas biológicas e fisiológicas em animais. Entre essas substâncias, encontram-se 
os inibidores de tripsina, hemaglutininas, saponinas, substâncias bocígenas, lipoxigenases, urease e outros fatores, tais como oligossacarídeos causadores de flatulência, provocada pela fermentação microbiana da rafinose e estaquiose as quais não sofrem digestão nos seres humanos, carentes da enzima alfa-galactosidase (Thananunkul et al., 1976; Basenhop \& Wilkens, 1969).

Os inibidores de tripsina e hemaglutininas reduzem a digestão protéica, provocam hipertrofia pancreática (Kakade et al. ${ }^{1}$,citados por Yoshida e Kajimoto, 1988), estimulam a hiper e a hiposecreção de enzimas pancreáticas e reduzem a disponibilidade de minerais e aminoácidos (Rackis ${ }^{2}$, citado por Yoshida \& Kajimoto, 1988) sendo que todos esses efeitos estão relacionados.

A inibição da proteólise intestinal, resultado da formação de complexos dos inibidores de tripsina e quimiotripsina no íleo (Rajkó \& Szabó et al., 1977), provoca um aumento de secreção das enzimas digestivas tripsina e quimiotripsina, as quais são eliminadas nas fezes, havendo então uma perda endógena importante de aminoácidos sulfurados, ocasionando um impacto nutricional maior, já que as leguminosas são deficientes nesses aminoácidos (Genovese \& Lajolo, 1988; Rackis, 1981).

Por essa razão, aplicar tratamento térmico para remover fatores antinutricionais é essencial para a utilização da soja na alimentação (Yoshida \& Kajimoto, 1998).

Savage et al. (1995) observaram que uma inativação de $80 \%$ da atividade do inibidor de tripsina foi obtida nos grãos de soja decorticados, submetidos ao branqueamento a $100^{\circ} \mathrm{C}$ por 12 minutos. E, de acordo com Rackins et al.,(1975), apenas 50 - 60\% de redução do inibidor de tripsina são exigidas para evitar a hipertrofia pancreática em ratos.Também o inibidor de tripsina pode ser mais facilmente destruído quando bicarbonato de sódio é adicionado à água de branqueamento, independentemente do tratamento de maceração (Nelson et al., 1976).

Há dois grupos de sabores indesejáveis nos produtos protéicos de soja. Um deles é composto pelos voláteis, responsáveis pelo sabor herbáceo ou feijão cru, e

1- KAKADE, M.L., SIMONS, N.R., LIENER, I.C., et al. Biochemical and nutricional assessments of different varieties of soybeans. Journal Agricultural Food Chemist's. v.20, n.87, 1972.

2- RACKIS, J.J. Phyisiological properties of soybean trypsin inhibitors and their relationship to pancreatic hypertrophy and growth inhibitor of rats. Fed. Pro, n.24, 1448p, 1965. 
outro pelos compostos não voláteis, responsáveis pelo sabor amargo e adstringente. Os primeiros são oriundos da deterioração oxidativa de ácidos graxos sob a ação da lipoxigenase e estes últimos, formados por deterioração oxidativa de aminoácidos e por hidrólise enzímica (Gomes et al., 1989).

As lipoxigenases catalisam a hidroperoxidação de ácidos graxos poliinsaturados, cujos produtos de degradação estão associados com 0 desenvolvimento desses sabores (Paula et al., 1995). Entretanto, com tratamento térmico apropriado da soja e de seus produtos, pode-se destruir total ou parcialmente a maioria das substâncias antinutritivas, permitindo assim, uma utilização máxima dos nutrientes pelo homem e pelos animais (Liener, 1979; Baker \& Rackis, 1985).

A sensação adstringente é atribuída a substâncias polifenólicas, interagindo com mucoproteínas na boca e garganta. No Oriente, o leite de soja geralmente é consumido quente. Chien \& Snyder (1983) pesquisaram o efeito da temperatura sobre a sensação adstringente, e observaram diminuição da adstringência quando leite de soja foi servido a $65-68^{\circ} \mathrm{C}$, comparados a $22-25^{\circ} \mathrm{C}$ ou $4-7^{\circ} \mathrm{C}$.

Não houve diferença na sensação adstringente entre o leite de soja degustado a $22-25^{\circ} \mathrm{C}$ e a $4-7^{\circ} \mathrm{C}$. Esses resultados mostram que Orientais geralmente consomem o leite de soja aquecido, pelas suas vantagens na sensação adstringente menor.

Os agentes mascarantes, que vêm sendo muito utilizados para encobrir o sabor característico da soja, não resolvem bem o problema, pois a canela, o cravo, o chocolate, o guaraná e outros aditivos, tornam o leite de soja enjoativo quando consumido freqüentemente. $\mathrm{O}$ ideal mesmo seria eliminar, ou pelo menos atenuar, o efeito das substâncias responsáveis por esse sabor característico da soja (Miya et al., 1975; Ferreira \& Shirose, 1977).

Ferreira \& Shirose (1976) pesquisaram a aromatização do leite de soja com morango, chocolate, coco, groselha, baunilha, abacaxi e banana em crianças em idade escolar e concluíram que não houve diferença significativa na aceitação do produto pelas crianças, sendo uma boa perspectiva para a introdução do leite de soja em grupos escolares que tem como alunos são crianças de diferentes classes sócio-econômicas.

Nos últimos anos, tem-se verificado um crescente desenvolvimento da 
tecnologia de fabricação do leite de soja (Munoz, 1998). As características organoléticas do produto final têm sido estudadas, considerando os fatores que mais restringem a aceitação deste produto (Huhn, 1977). Também a quantidade e a qualidade das proteínas são fatores relevantes a serem considerados, quando se trata de técnicas de processamento para extração deste nutriente da soja (Battisti, 1992 \& Bourne et al., 1976). Com relação à quantidade da proteína do leite de soja, um dos fatores de influência é a variedade da soja utilizada. O leite rico em proteínas depende da quantidade de proteínas solúveis em água e presente nos grãos (Bourne et al., 1976).

\subsection{Lipoxigenases}

As lipoxigenases constituem um importante fator na geração, a partir de lipídeos, dos compostos responsáveis pelo sabor desagradável quando grãos de soja são processados sob condições de alta umidade, como na preparação de leite de soja pelo processo tradicional (Wolf, 1975).

São importantes no desenvolvimento do sabor e aroma característicos de muitos frutos e vegetais de forma benéfica, mas também, na deterioração da qualidade dos alimentos e na geração de sabor e aroma desagradáveis em muitos alimentos, particularmente de sementes leguminosas tais como soja, ervilha e lentilha (Rackins et al., 1979).

A lipoxigenase, por definição, catalisa a oxidação de lipídeos contendo um sistema cis, cis, pentadieno, pelo oxigênio molecular, dando origem a hidroperóxidos.

A oxidação de lipídeos é um fenômeno muito comum em sementes oleaginosas e em seus produtos. Sabe-se que esse fenômeno é facilitado ou catalisado por muitos fatores como luz, oxigênio, calor, umidade, microorganismos, íns metálicos e enzimas (St. Angelo et al. 1979; Borham, 1979).

A hidroperoxidação dos ácidos graxos poliinsaturados inicia-se logo após o esmagamento dos grãos ou danos mecânicos, liberando enzimas e substratos que, até 
então estavam compartimentalizados, mas se houver a adição de água a reação ocorre com maior intensidade (Bordignon \& Mandarino, 1994). Daí a inativação térmica das enzimas antes da desintegração (Rackins et al., 1979). Foi descoberta em 1928, provocando a destruição do caroteno, o que the valeu a denominação de "caroteno oxidase". Caroteno oxidase e lipoxidase são a mesma enzima, a qual atualmente também é conhecida como lipoxigenase, com a propriedade catalítica de oxidar ácidos graxos insaturados (Witaker, 1972).

Para estudar a especificidade do substrato da lipoxigenase, Holman et al. (1969) utilizaram uma série de ácidos graxos poliinsaturados, com diferentes comprimentos de cadeia, número e posições de duplas ligações. Os autores chegaram à conclusão que a atividade ótima de reação é obtida com o ácido graxo que contém duplas ligações nos átomos 6 e 9 de carbono, contados a partir do grupo metila, cuja carbonila terminal não está estericamente impedida. $O$ isômero 9,12 é o melhor substrato, enquanto o 13,16 é menos especifico.

\subsection{Condições para atuação das lipoxigenases na soja}

Segundo Nelson et al. (1976), quando o tecido do cotilédone do grão de soja é danificado ou rompido, a enzima lipoxigenase, bem como o substrato lipídico são liberados. Enquanto o tecido estiver seco (aproximadamente 13\% de umidade), a enzima não catalisa a oxidação do substrato. Entretanto, se a água é absorvida a temperaturas abaixo daquela em que essas enzimas são inativadas, a reação ocorre rapidamente e produz "odor de feijão" ou "sabor de oxidado", altamente rejeitáveis, os quais são aceitos apenas pelos Orientais que desenvolveram paladar tolerante a eles.

O grão de soja contém quantidades expressivas das isozimas lipoxigenases LOX 1, LOX 2 e LOX 3 e de seus substratos, ácidos linoléico e linolênico, que entram em contato direto durante o processamento dos grãos. A ação catalítica, exercida por essas isozimas sobre os ácidos graxos poliinsaturados, é um dos principais fatores responsáveis pelo aparecimento de compostos carbonílicos de cadeia curta, como 
aldeídos, álcoois, cetonas e hidrocarbonetos, resultantes da degradação dos hidroperóxidos formados. Estes compostos associam-se às proteínas, limitando a utilização dos produtos protéicos de soja, por conferir-lhes sabores desagradáveis, de acordo com os padrões de aceitabilidade ocidental (Rackins et al., 1979).

Diversos pesquisadores contribuíram para evidenciar as condições em que as lipoxigenases atuam na oxidação lipídica.

Wilkens et al. (1967) determinaram que a rápida formação (quase instantânea) do sabor oxidado durante a trituração de grãos de soja com água é devido à oxidação de lipídeos poliinsaturados, catalisada por lipoxidases. Demonstraram ainda que, se a soja for moída junto com água, à temperatura próxima a $100^{\circ} \mathrm{C}$, quase toda a formação de sabor estranho desaparece e o leite obtido é suave.

Para o leite ser obtido pelo processo tradicional, $100 \mathrm{~g}$ de grãos são colocados em vasilha com água $(500 \mathrm{ml})$, em maceração por 8 a 12 horas, à temperatura de $20^{\circ} \mathrm{C}$. Para uma duração mais curta, eleva-se a temperatura $\left(\right.$ a $40^{\circ} \mathrm{C}$ ) por 4 a 8 horas. Temperaturas muito altas afetam a qualidade da proteína e durações muito longas podem abrigar fermentações indesejáveis no meio líquido.

Terminada a maceração, procede-se ao descascamento, seguido de várias lavagens em água corrente. Os grãos descorticados devem ser moídos em pilão, moedor de carne ou liquidificadores. Neste último caso, faz-se necessária a adição de água potável, da ordem de 6 a 8 vezes o volume da soja antes da trituração, ao contrário dos primeiros. Segue-se fervura por 6 a 20 minutos e filtração em coador de flanela. Ao leite coado pode ser adicionado açúcar e chocolate ou essência de baunilha para mascarar os sabores estranhos que apresenta (Câmara et al.,1982).

Wang et al. (1979) estudaram as alterações que ocorrem em várias condições de hidratação de grãos de soja e seus efeitos e concluiram que sólidos solúveis são lixiviados dos grãos, em proporções razoavelmente constantes durante toda a hidratação, e as quantidades lixiviadas são maiores a temperaturas mais elevadas. A temperatura é o fator mais importante na velocidade de absorção de água e na perda de sólidos. Do total de sólidos perdidos (que chega a 10,4\% após 24 horas a $37^{\circ} \mathrm{C}$ ), 7 a $16 \%$ são proteinas em macerações de 2 horas a $20^{\circ} \mathrm{C}$ e, de 24 horas a $37^{\circ} \mathrm{C}$, 
respectivamente. A proporção de proteína perdida aumenta com o aumento do tempo e da temperatura de hidratação.

Assim, seria razoável considerar que também as lipoxigenases, que se encontram no citoplasma das células dos cotilédones, sejam liberadas na maceração, podendo entrar em contato com os corpos lipídicos e atuar na catálise da oxidação dos ácidos graxos (Song et al., 1990). A obtenção de cultivares de soja com a ausência de lipoxigenase é uma alternativa na tentativa de minimizar os problemas de sabor e odor dos produtos protéicos de soja (Gomes et al., 1995).

\subsection{Processos existentes para a produção de leite de soja}

Dentre os muitos métodos para produção de leite de soja, Kwok (1995) resumiu alguns processos que são apresentados na Tabela 1 . O processamento pode seguir um método ou uma combinação desses métodos, para produção de leite de soja nutritivo, com alto rendimento em sólidos e proteínas e de boa palatabilidade .

O processo tradicional para a produção de leite de soja, que tem sido utilizado por vários séculos no Oriente, envolve a maceração dos grãos em água, seguida por trituração, filtração e fervura. Embora este processo seja simples, a bebida resultante tem odor e flavor desagradáveis, característicos de tinta (ou óleo de linhaça) (Nelson et al.,1976). Neste mesmo processo, Cabral et al.,(1997) alcançou sucesso na obtenção do leite de soja com sabor suave e boa solubilidade, através da incorporação do branqueamento dos grãos de soja, favorecendo a inativação de lipoxigenase e do inibidor de tripsina.

Segundo Golbitz (1995), leite de soja é produto da extração aquosa de grãos inteiros da soja. Particularmente importante foi a identificação e inativação de componentes primariamente responsáveis pelo "sabor de grão" em leite de soja. Acreditase que a enzima responsável pelo desenvolvimento no leite de soja seja inativada pelo uso de água fervente na etapa de moagem. $O$ uso de branqueamento com água quente e bicarbonato de sódio antes da moagem também diminui o sabor desagradável. 
Tabela 1. Métodos de obtenção de leite de soja

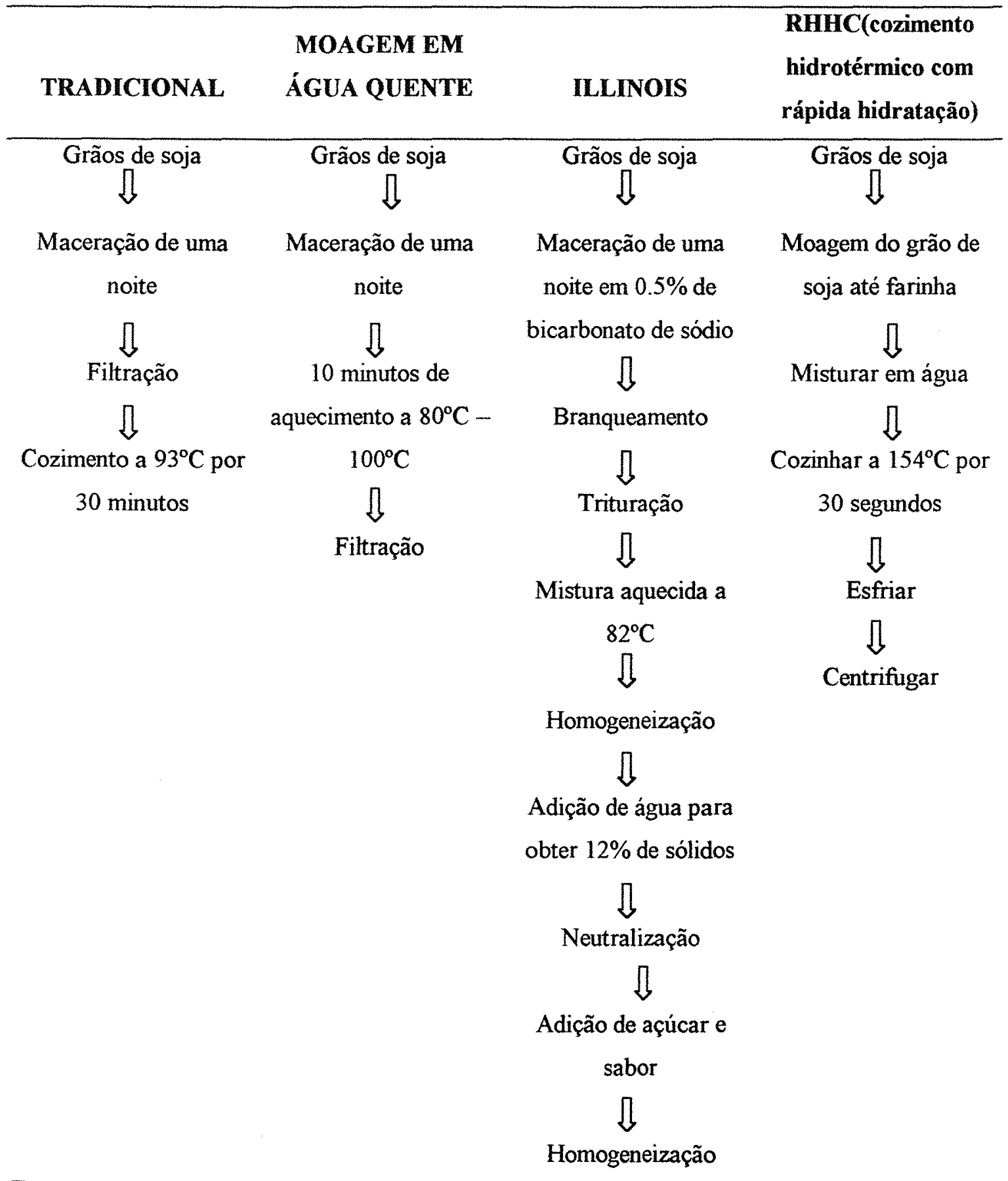

Fonte: Kwok, 1995 
Wilkens et al. (1967) estiveram entre os primeiros a identificar a atuação das lipoxigenases na maceração dos grãos de soja como responsáveis pelo desenvolvimento do sabor desagradável e a propor um processo de extração com água quente para inibi-las. Desde então, inúmeros trabalhos surgiram, propondo os mais diversos métodos para a inativação das lipoxigenases e obtenção do leite de soja com sabor e aroma agradáveis aos consumidores do Ocidente. $O$ tratamento térmico é ainda, o mais utilizado, segundo Paula et al. (1995), podendo, quando inadequado, desnaturar e insolubilizar as frações protéicas, limitando assim sua utilização.

Backer \& Mustakas (1973) estudaram os efeitos de aditivos químicos na inativação térmica de inibidores de tripsina, lipoxigenases e urease e verificaram que, com a adição de ácidos ( $\mathrm{NaOH})$ e bases (bicarbonato de sódio), a inativação inicial de urease e das lipoxigenases foi significativamente acelerada. Sem aditivos, a completa inativação das lipoxigenases foi alcançada após 15 minutos a $180^{\circ} \mathrm{F}\left(82^{\circ} \mathrm{C}\right)$. A $120^{\circ} \mathrm{F}$ $\left(49^{\circ} \mathrm{C}\right)$ não houve inativação.

Wang \& Toledo (1990) demonstraram em seus estudos, que a radiação de microondas penetra rapidamente nos produtos alimentícios, tendo como resultado a formação de calor em tempos inferiores àqueles utilizados pelos processos até então descritos. Baseados nesse princípio, avaliaram o valor nutricional do leite de soja preparado a partir de grãos tratados com microondas. Concluíram que, com este tipo de tratamento, obtêm-se produtos com alta digestibilidade de proteína "in vitro", aumento dos aminoácidos que contêm enxofre e redução da atividade inibidora da tripsina, além da rápida inativação da lipoxigenase. Também foi observado que, com maior umidade inicial dos grãos de soja, os valores de atividade de lipoxigenase e a atividade residual de antitripsina obtidos, eram menores que nos grãos com menor umidade.

Che Man et al. (1989) avaliaram um método de inativar as lipoxigenases da soja com retenção da solubilidade da proteína, usando apenas ácido, sem o emprego de calor. Segundo esses autores, a inativação das lipoxigenases é irreversivel quando a soja é triturada em meios com pH menor que 3,0 independentemente do ácido utilizado.

Badenhop \& Hackler (1970) estudaram os efeitos da maceração dos grãos de soja em soluções de hidróxido de sódio sobre o sabor e aroma, a aceitação e o valor 
nutricional do leite resultante e verificaram uma melhora no sabor, no aroma e na aceitação do leite de soja sem apresentar alterações no seu valor nutritivo. Concluíram que a maceração dos grãos de soja em solução de hidróxido de sódio $0,05 \mathrm{~N}$, por duas horas a $50^{\circ} \mathrm{C}$, foi um pré-tratamento recomendável antes da operação de trituração em altas temperaturas para a produção do leite.

Geromazzo et al. (1998) conseguiram inativação, tanto das lipoxigenases como das antitripsinas com moagem direta e aplicação de alta temperatura. Entretanto Rajkó \& Szabó (1997), após compararem diversos tratamentos, como fervura, aplicação de vapor, secagem, energia de microondas, tostagem e aplicação de pressão, observaram que, para aumentar o beneficio biológico, facilitar a digestão e inativar os antinutricionais, o método que utiliza a energia de microondas é mais eficiente do que os tradicionais tratamentos térmicos, visto assegurar homogeneidade completa de aplicação de calor no volume total da amostra na operação.

Gomes et al.,(1989) trabalhou com dois cultivares comerciais de soja com alta e baixa atividade de lipoxigenase, UFV-5 e BR 5 , respectivamente, e relacionou a presença do hexanal com as propriedades organoléticas. A presença do hexanal no leite de soja indica a ocorrência de oxidação lipídica e geração de compostos secundários, também provocada pela ação da lipoxigenase.

Através da análise sensorial, foram detectadas diferenças significativas entre as variedades e os métodos de extração testados. A variedade BR5 foi a que apresentou menor teor de hexanal e o hexanal influenciou nas respostas dos provadores, pois contribuiu consideravelmente para o sabor earoma do extrato solúvel de soja.

\subsection{Adstringência e sabor amargo}

Os sabores são os principais fatores que limitam o uso de produtos à base de soja, pois suas qualidades sensoriais afetam a aceitação do produto final (Santos, 1993).

As isoflavonas têm sido responsabilizadas pelos sabores amargo e adstringente em produtos à base de soja. As isoflavonas constituem o principal grupo dos 
isoflavonóides ou 3 fenilbenzeno $\delta$-pirano. A genisteína e daidzeína são os principais isoflavonóides da soja, encontrados na forma de glicosídeos, os quais podem sofrer alterações químicas durante o processamento, e atribuírem ao extrato hidrossolúvel de soja sabor amargo e adstringente. A sensação adstringente é atribuída às substâncias polifenólicas interagindo com mucoproteínas na boca e garganta (Kwok,1995).

Okubo et al. (1981) estudaram os sabores dos produtos de grãos de soja e verificaram que as agluconas isoflavonas provocaram maior sabor adstringente que os glicosídeos isoflavônicos. Vários estudos têm sido realizados com o objetivo de neutralizar a ação desses compostos e melhorar as qualidades organoléticas dos produtos obtidos da soja.

Chien \& Snyder (1983) mostraram que o leite de soja apresenta sabor menos adstringente com a adição de $\mathrm{CaSO}_{4}$ ou ácido cítrico.

Matsuura et al. (1983) acompanharam os teores de daidzeína e genisteína no sabor do leite. A concentração de daidzeína e genisteína é aumentada pela ação da enzima $\beta$-glucosidase durante a maceração, que é o primeiro passo para a produção de extrato hidrossolúvel de soja. O aparecimento desses compostos isoflavônicos está relacionado com o pH e a temperatura da água de maceração. Esta enzima pode ser inibida com os compostos glucona- $\delta$-lactona e nojirimicina que atuam de forma competitiva (Santos, 1993). A maceração em meio alcalino extrai os compostos fenólicos de grãos de soja (Oh et al., 1988). Os compostos fenólicos, em geral, podem ser quase inteiramente removidos pela maceração em solução de $\mathrm{NaOH} 0,1 \%$ por 8 horas a frio ou a $90^{\circ} \mathrm{C}$ por 1 hora.

Matsuura et al. (1989) propuseram um método para a obtenção de leite de soja com menor sabor desagradável. O primeiro passo seria a maceração em água, à temperatura ambiente, contendo glucona- $\delta$-lactona para inibir a $\beta$-glucosidase e evitar a hidrólise dos glucosídeos em compostos fenólicos que formariam a daidzeína $\mathrm{e}$ genisteína. $O$ segundo passo seria a moagem a quente, onde haveria completa inativação das $\beta$-glucosidases e lipoxigenases.

Remove-se, em grande parte, o sabor inicial da soja por aquecimento úmido, e a inativação dos sistemas enzímicos oxidantes pelo calor ajuda a reduzir o 
desenvolvimento de outros sabores desagradáveis. Alguns sabores residuais ainda permanecem como problema na utilização de muitos produtos derivados da soja (Arkocoll, 1976).

\subsection{Avaliação sensorial}

A análise sensorial é usada para provocar, medir, analisar e interpretar as reações produzidas pelas características dos alimentos e materiais, como elas são percebidas pelos órgãos da visão, olfato, gosto, tato e audição (Amerine et al., 1965).

Depois de 1970, definiu-se qualidade sensorial de um alimento, não como uma característica própria, mas sim como o resultado da interação entre o alimento e o homem. Reconhece-se que a qualidade sensorial é função, tanto dos estímulos procedentes dos alimentos como também das condições fisiológicas, psicológicas e sociológicas do indivíduo ou grupo que avalia o alimento (Dutcosky, 1996).

\subsubsection{Análise Descritiva Quantitativa (A.D.Q)}

Nos atuais estudos objetivos e subjetivos do sabor, muitas técnicas de avaliação têm-se direcionado aos métodos sensoriais, destinados a eliminar as preferências pessoais nas avaliações. As variáveis que influenciam a aceitação e consumo dos alimentos relacionam-se com: 1) as características do indivíduo a quem o alimento se destina, tais como renda, nível educacional, idade, sexo, conhecimentos nutricionais, hábitos culinários, atitudes com relação a aspecto de saúde, etc., 2) as características do alimento, como aparência, aroma, sabor, textura, preço, método de preparo, etc., 3) as características do ambiente onde o consumidor se insere, como tipo de domicilio, características familiares, grau de urbanização, estação do ano, etc.

Devido à natureza das informações necessárias para os propósitos de correlação, o método de Análise Descritiva parece ser o mais satisfatório. O método mais conhecido e o mais usado em desenvolvimento de trabalhos de pesquisa é Perfil Sensorial, o qual utiliza pequenos números de provadores especificamente treinados (Sjöström, 1968). 
A Análise Descritiva representa a mais sofisticada das metodologias de avaliação sensorial, comparada com os testes de aceitação e diferença. Os resultados incluem uma descrição sensorial completa dos produtos teste e fornecem a base para a determinação das características sensoriais que são importantes para a aceitação. $O$ método é capaz de relacionar os ingredientes específicos ou processos variáveis com mudanças específicas nas características sensoriais de um produto (Stone et al., 1974).

A Análise de Perfil Sensorial é um método que fornece informações qualitativas do alimento. Assim, novos métodos descritivos foram desenvolvidos a fim de quantificar essas informações. Dentre eles é citado o método de Análise Descritiva Quantitativa (Stone et al. 1974), o qual identifica, descreve e quantifica os atributos sensoriais do produto. A Análise Descritiva Quantitativa é uma ferramenta valiosa para aumentar a informação sobre a aparência, aroma, sabor e textura dos produtos, e é usada efetivamente para produtos e processos em desenvolvimento, estudos de prateleira, controle de qualidade, e correlações objetivo-subjetivas nas avaliações dos alimentos (Gillette, 1996). 


\section{MATERIAL E MÉTODOS}

\subsection{Material}

Foram utilizados grãos de soja da cultivar FT 109, da safra 1998/1999, obtidos do Departamento de Produção Vegetal da Escola Superior de Agricultura "Luiz de Queiróz". Para as macerações dos grãos íntegros e preparo das diversas soluções de maceração, utilizou-se água mineral obtida no comércio local.

\subsection{Métodos}

\subsubsection{Produção de leite de soja}

Dois métodos de obtenção de leite de soja foram utilizados:

I) Processo Illinois Adaptado

Este método foi desenvolvido por Nelson et al. (1976) e, reconhecidamente, produz um leite de soja de boa qualidade. $\mathrm{O}$ método adotado sofreu algumas pequenas alterações. Grãos de soja integros e em boas condições, selecionados manualmente, foram submetidos à maceração durante 12 horas à temperatura ambiente. Pesaram-se $50 \mathrm{~g}$ de grãos que foram imersos em água $(150 \mathrm{ml})$ à temperatura ambiente (absorção de água aproximadamente 1,1 vezes a massa inicial) com $0,75 \mathrm{~g}$ de bicarbonato de sódio. Após esse tempo, os grãos foram lavados e posteriormente macerados em banho-maria por 30 minutos, com mais $0,75 \mathrm{~g}$ de bicarbonato. Em seguida, foram novamente lavados e então homogeneizados com água num volume de $416 \mathrm{ml}$. 
II) Leite de soja obtido de grãos aquecidos em forno de microondas

Dois lotes, de 150g cada, de grãos de soja íntegros e selecionados manualmente, foram submetidos ao aquecimento em forno de microondas marca Sanyo, Modelo EM804 TGR, (2450 MHz, 800 Watts) pelos tempos de 140 e 150 segundos. Os lotes foram distribuídos proporcionalmente em três placas de Petri, de $10 \mathrm{~cm}$ de diâmetro com 50 gramas de grãos cada, as quais foram dispostas, lado a lado, na parte central do prato rotativo do microondas.

Para cada amostra de $50 \mathrm{~g}$ utilizaram-se $150 \mathrm{ml}$ de água para macerar os grãos em banho-maria por 1 hora, sendo em seguida, cada uma, homogeneizada em liqüidificador com $300 \mathrm{ml}$ de água e coada, obtendo-se assim três amostras de dois tipos de leite para serem avaliados sensorialmente e caracterizados através de análises químicas e fisicas.

\subsubsection{Caracterização analítica do leite se soja}

Os leites de soja obtidos para este estudo foram caracterizados pelo teor de óleo, de acordo com Folch et al. (1957), pelo teor de proteína bruta, de acordo com a AOCS (1990), pelo teor de umidade e de cinza, segundo AOAC (1995), e o teor de carboidratos totais foi calculado pela diferença percentual.

\subsubsection{Determinação da atividade da urease}

Determinada nos grãos aquecidos no microondas resfriados e triturados em moinhos tipo Wiley, a fração analisada compôs, no mínimo, $60 \%$ do peneirado através de malha 40 Mesh U.S Standard (AACC, 1969).

Foi pesado $0,200 \mathrm{~g}$ da amostra preparada, em triplicata, em tubo teste, adicionando-se $10 \mathrm{ml}$ de solução tampão uréia, agitado-se e colocando-se em banho maria a $30^{\circ} \mathrm{C}$. Foi preparada também uma prova em "branco" de soja, tratada da mesma forma: $0,200 \mathrm{~g}$ de amostra em um tubo teste, adicionado de $10 \mathrm{ml}$ de solução de potássio 
fosfatado e também levada ao banho-maria. Os tubos teste foram agitados a cada 5 minutos até completar 30 minutos. Após este período, realizou-se a leitura do $\mathrm{pH}$ do sobrenadante de cada amostra.

Assim, a partir da diferença do $\mathrm{pH}$ do teste com o $\mathrm{pH}$ do "branco", foi possível determinar indiretamente a atividade ureática.

\subsubsection{Solubilidade protéica}

Os mesmos tempos foram avaliados quanto à qualidade da proteína, isto é, quanto à capacidade de solubilização, conforme a metodologia da AOCS (1983).

\subsubsection{Análise Sensorial}

A análise sensorial envolveu duas fases distintas: a primeira fase constou da seleção das amostras, cuja finalidade foi a de promover a padronização do volume de água utilizado na diluição do leite de soja; e a segunda fase constou da caracterização sensorial do leite de soja, submetido ao processo de aquecimento por microondas.

\subsubsection{Seleção das amostras}

Para a seleção das amostras, foi aplicado o Teste de Ordenação (Kramer et al., 1974), com escalas de preferência para padronização dos tratamentos a serem utilizados posteriormente na análise descritiva. Os testes envolveram de 20 a 30 provadores não treinados, os quais ordenaram as amostras em escala decrescente, variando de mais aceitável a menos aceitável. As amostras foram servidas em copos descartáveis de $25 \mathrm{ml}$ e codificadas com números de 3 dígitos e dispostos aleatoriamente em bandejas, juntamente com água para a lavagem dos palatos. $O$ esquema das fichas encontra-se na Figura 1. 
Nome: Data: 11 Você está recebendo 3 amostras de produto à base de soja. Por favor, prove as amostras e ordene-as de acordo com a sua preferência. Obrigada.

+ preferida

- preferida

Comentários:

Figura 1- Modelo de ficha de ordenação

Foram aplicados 2 testes de ordenação. Os tratamentos utilizados nesse primeiro teste foram os seguintes: processo Illinois; leite de soja aquecida por 140 segundos no microondas e triturada com $300 \mathrm{ml}$ de água; leite de soja aquecida por 140 segundos no microondas e triturada com $350 \mathrm{ml}$ de água e leite de soja aquecida por 140 segundos no microondas e triturada com $400 \mathrm{ml}$ de água. Pelos resultados obtidos nesse primeiro teste, o tratamento com leite de soja aquecida por 140 segundos no microondas e triturada com $300 \mathrm{ml}$ de água foi o preferido em relação aos demais.

Outros tratamentos realizados foram: leite de soja aquecida por 150 segundos no microondas triturada com $300 \mathrm{ml}$ de água; leite de soja aquecida por 150 segundos no microondas e triturada em $350 \mathrm{ml}$ de água e leite de soja aquecida por 150 segundos no microondas e triturada com $400 \mathrm{ml}$ de água. Pelos resultados obtidos, o tratamento com leite de soja aquecida por 150 segundos no microondas e triturada com $300 \mathrm{ml}$ de água, foi o preferido em relação aos demais.

\subsubsection{Caracterização do leite de soja}

Para a caracterização do leite de soja, submetido aos diferentes processos, foi necessário selecionar e treinar os integrantes da equipe de provadores. A composição da equipe foi conduzida, aplicando-se métodos analíticos de diferença para seleção de 
provadores e método descritivo para medir a qualidade do extrato hidrossolúvel de soja, através da "Análise Descritiva Quantitativa" (A.D.Q.), usando-se uma escala não estruturada de 0 a $10 \mathrm{~cm}$ (Stone et al., 1974).

\subsubsection{Recrutamento e seleção da equipe de provadores}

Para se realizar o recrutamento de provadores, levou-se em consideração a disponibilidade de tempo do provador, suas habilidades na percepção de diferenças de sabores e aromas da amostra, interesse em participar da equipe, apreciar ou não o produto.

A equipe de provadores foi constituída de 5 homens e 7 mulheres, na faixa etária de 20 a 40 anos, constituindo-se de pesquisadores, técnicos, mestrandos e secretárias do Departamento de Agroindústria, Alimentos e Nutrição da Escola Superior de Agricultura "Luiz de Queiroz". Os testes foram desenvolvidos em duas fases distintas: seleção e treinamento dos provadores e avaliação sensorial na qualidade do leite de soja. A seleção dos provadores foi realizada segundo o teste de reconhecimento de gostos básicos (Amerine et al., 1965) e o Teste Triangular.

O teste de reconhecimento de gostos básicos (Amerine et al., 1965) foi realizado utilizando-se, como material, soluções quimicamente puras dos gostos básicos: doce $(0,14 \%$ de sacarose), ácido $(0,07 \%$ ácido cítrico), salgado ( $0,5 \%$ cloreto de sódio), amargo ( $0,07 \%$ cafeína). Essas soluções foram oferecidas aos provadores em copos plásticos descartáveis, arranjados aleatoriamente em bandejas, através de uma tabela de números aleatórios de 3 algarismos (Fisher \& Yates, 1971).

$\mathrm{O}$ teste de reconhecimento dos sabores foi conduzido em sala com temperatura controlada $\left(22^{\circ} \mathrm{C}\right)$, estando os provadores individualizados, em cabines próprias para Análise Sensorial. Cada cabine continha bandejas com as amostras, fichas de avaliação, (Figura 2), e copos com água para a lavagem dos palatos entre as avaliações. Uma vez provadas as amostras, estas eram discriminadas nas fichas, para as qualidades de gosto. As fichas, por sua vez, foram comprovadas com os códigos das amostras, para 
determinar se algum provador era portador de "ageusia", através da porcentagem de acertos. Este procedimento foi realizado com repetição, excluindo-se os provadores que não atingiram a margem de $100 \%$ de acertos nas duas baterias de provas.

Nome:

Data :

INSTRUÇÕES: Por favor, prove as amostras, identificando os gostos básicos (ácido, doce, amargo e salgado), na frente das numerações das amostras. Lave a boca após provar cada amostra.

AMOSTRA(N. $\left.{ }^{\circ}\right)$

GOSTO
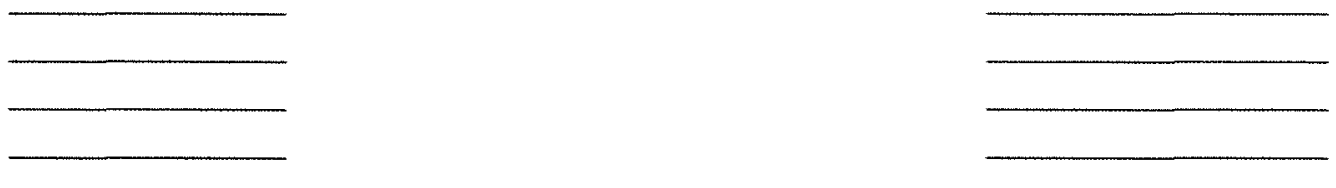

Figura 2 - Modelo de ficha de identificação de gostos básicos

$O$ teste de sensitividade para gosto foi realizado empregando-se o Teste Triangular (Helm \& Trolle, 1946; Garruti, 1976), utilizando-se como amostras os próprios tratamentos do experimento. As amostras eram apresentadas duas a duas e o provador era solicitado a identificar a diferença entre elas (Figura 3). Foram realizados doze testes, excluindo-se os provadores que não atingiram a margem de $75 \%$ de acertos nas baterias de provas. 
Nome:

Data:

1

INSTRUÇÕES: Duas dessas três amostras são iguais e uma é diferente.

Por favor, prove da esquerda para a direita, com intervalo de 20 segundos entre as amostras e indique a amostra diferente, fazendo um círculo ao redor do número. Lave a boca após provar cada amostra. Obrigada.

\section{N. ${ }^{\circ}$ DAS AMOSTRAS}

1)

2)

3)

Figura 3 - Modelo da ficha do Teste Triangular.

\subsubsection{Treinamento}

Após a seleção dos provadores, procedeu-se à fase de treinamento da Análise Descritiva Quantitativa (A.D.Q), a qual constou de uma preleção aos provadores pelo supervisor, objetivando-se desenvolver terminologia descritiva na identificação dos atributos de aparência, sabor, aroma e textura; e de familiarizar os provadores com a escala a ser usada para medida da intensidade de cada atributo. 


\subsubsection{Desenvolvimento de terminologia descritiva}

Os termos descritivos, obtidos pela técnica de perfil livre de amostra de extrato hidrossolúvel de soja, são apresentados a seguir:

\begin{tabular}{|llll|}
\hline Escuro & Amargo & Denso & Consistente \\
Parece leite de vaca & Gosto verde & Fluido & Líquido sem grânulos \\
Boa & Pouco aguado & Viscoso & Suave \\
Regular & Cru/ adocicado & Leitoso & Apresenta certo brilho \\
Ótima & Ralo & Oleoso & Homogêneo \\
Branca & Forte & Levemente gorduroso & Nada oleoso \\
Amarela & Fraco & Pouca gordura & Uniforme \\
Branco levemente & Bastante adstringente & Pouco oleoso & Soro \\
esarrecido & Cremoso & Ruim & Aguado \\
Quase branco & Lesado & Ligeiramente gorduroso & Encorpado \\
Branco cremoso & Agradável & Bom & Lisa \\
Creme & Arranha a boca & Característico & Suco de abacaxi \\
Cor palha & Lembra produto cru & Gosto ácido & Atraente \\
Leite moça & Meio ardido & Quase inodoro & Pouca consistência \\
Opaca & Sem cheiro & Gorduroso & Leite ralo \\
Brilhante & Cheiro de soja & Bastante diluída & Não agradável \\
Óleo de soja & Água de arroz & Parece que sustenta & Aroma de leite \\
Líquida & Pouco adstringente & Torrado & Aroma de grão verde \\
Leitoso & Poucocaracteristionde soja & Meio amargo & Encorpado \\
Suculento & & & \\
\hline
\end{tabular}

Figura 4 - Termos descritivos obtidos pela técnica do perfil livre em amostras de extrato hidrossolúvel de soja.

Várias sessões de treinamento foram realizadas, em que esses atributos foram levantados.

Alguns termos foram eliminados, outros substituídos, tornando-se possível agrupá-los, formando um conjunto de 6 atributos de termos para aparência, 2 atributos para textura, 1 atributo para aroma e 5 atributos para sabor dos leites avaliados, completando-sea Análise de Perfil de Atributos do leite de soja, é apresentada a seguir: 


\section{APARÊENCIA:}

Cor: leite de vaca, branco, lembra cor de leite moça, leite de vaca caramelado

Brilho: soro, gorduroso, oleoso,

Característico: leite de soja cru, ralo, pouco consistente, soro de leite, fluido

Gorduroso: oleoso, gorduroso

Uniformidade: liso, uniforme

Consistência: líquido, leitoso, aguado, ralo, pouco consistente, cremoso, colostro AROMA

Cru: feijão cru, milho verde, aroma de leite

Torrado: queimado, torrado

\section{SABOR}

Ranço: leite de soja Illinois, manteiga rançada

Doce: adocicado, doce, suave

Ácido: ácido

Sabor: queimado, torrado, grão verde, amendoim, feijão cru, milho verde cru

Amargo: torrado, não queimado

TEXTURA:

Viscosidade: oleoso, viscoso, fluido

Consistência: denso, leitoso, diluído, ralo, consistente, encorpado

Figura 5 - Grupos de atributos relacionados pelos provadores, para o perfil de aroma, sabor, aparência e textura do leite de soja submetido a diferentes tratamentos.

Após a definição dos atributos, foram apresentadas várias amostras à equipe de provadores a fim de se definir os parâmetros que seriam utilizados como padrão de referência. A lista de definições dos termos descritivos com seus padrões de referência é apresentada a na Figura 6. 


\section{APARENCIA:}

COR: refere-se à brancura da amostra, variando de branco (nota 1) a cor de leite caramelado (nota 9).

Parâmetros: leite de vaca e leite de vaca caramelizado

BRILHO: refere-se à quantidade de brilho que cada amostra apresenta, variando de opaco (nota 1) a brilhante (nota 9).

Parâmetros: arroz cozido homogeneizado para opaco e gelatina de abacaxi para brilhante.

CARACTERÍSTICO: refere-se a caracterizar a amostra quanto à aparência característica do leite de soja, variando de pouco (nota 1) a muito característico (nota 9).

Parâmetros: para muito caracteristico foi usado extrato hidrossolúvel de soja cru e para pouco característico foi usado soro de leite de vaca.

GORDUROSO: refere-se a caracterizar o quanto de óleo a amostra apresenta, variando de pouco (nota 1) a muito gorduroso (nota 9).

Parâmetros: leite de soja com adição de leite de soja e leite de soja sem adição de óleo de soja.

UNIFORMIDADE: verificou-se a separação de fases aquosa e leitosa

Parâmetros: para pouco uniforme usou-se água com maisena (nota 1) e para uniforme usou-se leite integral longa vida (nota 9).

CONSISTÊNCIA: verificou-se a presença de corpo na amostra

Parâmetros: varia de aguado com o leite de soja diluído na proporção 1:8 (nota 1) e encorpado, sendo o leite de soja preparado com $150 \mathrm{ml}$ de água (nota 9).

2. AROMA: refere-se ao cheiro da amostra, variando de leite de soja (nota 1) cru a leite de soja torrado (nota 9).

Parâmetros: leite de soja preparado com soja sem tratamento e leite de soja preparado com soja torrada.

\section{SABOR}

Ranço: refere-se à caracterização do grau de oxidação do produto

Parâmetros: leite de soja puro (nota 1) e leite de soja adicionado de margarina rançada (nota 9 ).

Doce: refere-se a caracterizar o quanto a amostra apresenta o sabor adocicado, variando de pouco a muito doce.

Parâmetros: leite de soja sem açúcar (nota 1) e leite de soja com 10\% de açúcar (nota 9).

ÁCIDO: refere-se a caracterizar a acidez da amostra, variando de pouco a muito ácido.

Parâmetros: leite de soja preparado a partir do método Illinois (nota 1) e leite de soja acidificado com ácido cítrico até pH 3,5 (nota 9).

Sabor : (cru/ torrado) refere-se a caracterizar a amostra em relação ao sabor característico de leite de soja crua.

Parâmetros: leite de soja sem tratamento (nota 1) e leite de soja torrado (nota 9).

AMARGO: refere-se a caracterizar o amargor da amostra, variando de pouco a muito amargo.

Parâmetros: leite de vaca como pouco amargo (nota 1)e leite de soja com 0,05 de cafeína (nota 9).

4. TEXTURA

VISCOSIDADE ORGANOLÉTICA: verificou-se o tempo de aderência do leite na língua e palato após sua ingestão

Parâmetros: para fluido usou-se água (nota 1) e para viscoso mel com leite de soja na proporção de $50 \%$ cada (nota 9 ).

CONSISTÊNCIA ORGANOLÉTICA: verificou-se o grau de espalhamento do leite na boca antes da deglutição

Parâmetros: para fluido usou-se água (nota 1) e para encorpado usou-se leite integral (nota 9).

Figura 6 - Lista de definições dos termos descritivos para os atributos de aroma, sabor, aparência e textura do extrato hidrossolúvel de soja. 
A avaliação sensorial para o experimento foi realizada no mesmo ambiente e condições dos testes de reconhecimento de sabores. Os tratamentos utilizados na avaliação sensorial final foram: leite diluído em $300 \mathrm{ml}$ de água de soja aquecida por 140 segundos no microondas e leite diluído em $300 \mathrm{ml}$ de água de soja aquecido por 150 segundos no microondas, ambos aprovados no teste de ordenação e o método Illinois, considerado padrão no tratamento do leite de soja tradicional.

O método sensorial utilizado para a avaliação do sabor das amostras do experimento foi "Análise Descritiva Quantitativa" (A.D.Q). Para medida de intensidade de cada atributo foi usada uma escala não estruturada de 0 a $10 \mathrm{~cm}$ (Figura 7).

O delineamento experimental utilizado foram blocos casualizados, em que cada provador constituiu um bloco, num total de 12 blocos, com um único fator com 3 níveis (tratamentos 1, 2 e 3 ).

Os resultados obtidos foram submetidos à análise de Variância, com aplicação do teste $\mathrm{F}$. A análise estatística teve continuidade com o teste de Tukey, quando o valor $\mathrm{F}$ foi significativo ao nível de $5 \%$ de probabilidade. 


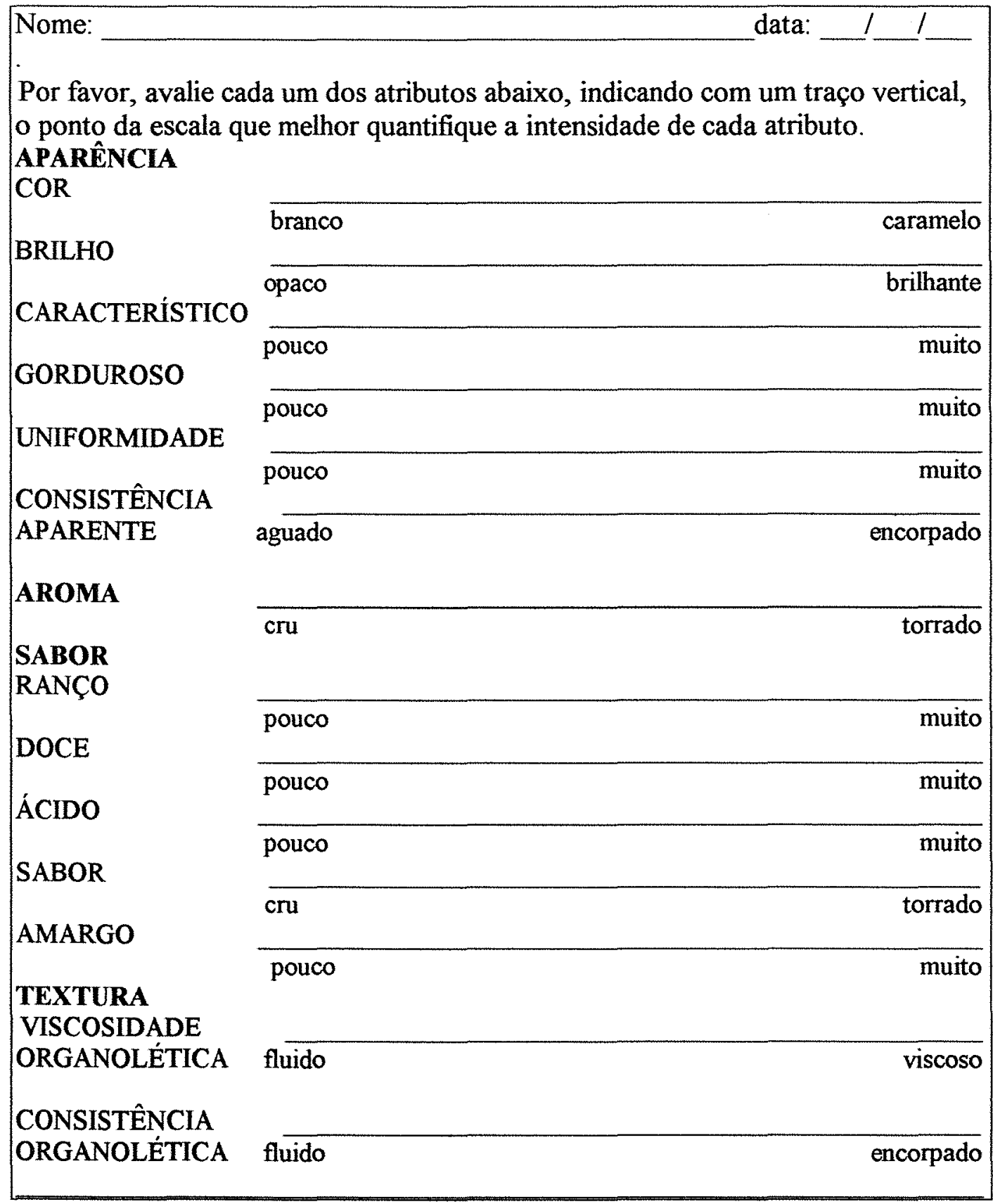

Figura 7 - Ficha de Análise Descritiva Quantitativa do extrato hidrossolúvel de soja. 


\subsubsection{Teste de aceitabilidade}

Para se verificar a aceitabilidade dos diferentes tratamentos, foi realizado um teste de aceitabilidade, com 25 provadores não treinados. $O$ teste foi realizado no Departamento de Agroindústria, Alimentos e Nutrição. As amostras foram servidas à temperatura ambiente, em quantidades em torno de $30 \mathrm{ml}$ cada, sob luz natural e codificadas com número de 3 dígitos e a apresentação foi aleatória. Utilizou-se uma escala hedônica de 9 pontos (gostei extremamente, desgostei extremamente). A ficha apresentada encontra-se na Figura 5.

Nome: Data:

1

Por favor, prove as amostras da esquerda para a direita e coloque o número das amostras na frente das notas que você escolheu. Obrigada.

9- Gostei extremamente

8- Gostei muitíssimo

7- Gostei muito

6- Gostei ligeiramente

5-Indiferente

4-Desgostei ligeiramente

3- Desgostei muito

2-Desgostei muitíssimo

1- Desgostei extremamente

Figura 8 - Ficha da Escala Hedônica do extrato hidrossolúvel de soja.

Para a avaliação dos dados, aplicou-se a análise da variância a $5 \%$ de probabilidade. As médias foram discriminadas pelo teste de Tukey.

\subsubsection{Análise Estatística}

Os resultados obtidos foram submetidos à análise estatística de acordo com 0 esquema de análise de variância e a análise estatística teve continuidade para o teste $\mathrm{F}$ significativo $(p<0,05)$, aplicando-se o Teste de Tukey $(\alpha=0,05)$, utilizando-se para isto o programa estatístico SAS (1988). 


\section{RESULTADOS E DISCUSSÃO}

\subsection{Características do extrato hidrossolúvel de soja}

\subsubsection{Composição química do extrato hidrossolúvel de soja}

A composição química dos extratos hidrossolúveis de soja encontra-se na Tabela2.

Tabela 2. Composição quimica dos extratos hidrossolúveis de soja (em base úmida).

\begin{tabular}{c|c|c|c}
\hline Parâmetro (\%) & 140 segundos & 150 segundos & Illinois \\
\hline Proteína & 0,37 & 0,35 & 1,20 \\
Óleo & 0.48 & 0.52 & 0.63 \\
Carboidratos & 1,45 & 1,79 & 2,19 \\
Cinza & 0.19 & 0.15 & 1.58 \\
Umidade & 97,51 & 97,51 & 94,40 \\
\hline
\end{tabular}

\subsubsection{Atividade da urease}

Os grãos da soja apresentaram atividades ureáticas decrescentes com o tempo de aquecimento no forno de microondas nos tempos de $140 \mathrm{~s}$ e $150 \mathrm{~s}$. O aumento do tempo de exposição dos grãos às microondas, provocou crescente inibição da atividade ureática como se pode observar na Tabela 3.

Atingida a inibição da urease nos diversos tempos de tratamentos iniciou-se a avaliação da qualidade protéica, já que tratamentos que utilizam de calor podem estar desnaturando as proteinas presentes na amostra, isto é, podem estar insolubilizando-as o 
que significa menor teor de proteínas no leite. Para esta avaliação foi utilizada o Índice de Solubilidade Protéica (NSI).

Períodos de 140 s e 150 s foram escolhidos para garantir a qualidade do leite, relacionados também com a atividade de antinutricionais o qual pode ser reduzido durante a maceração.

Tabela 3. Atividade ureática em soja, submetida a diferentes tempos de exposição ao microondas.

\begin{tabular}{ccc}
\hline Tempo (T/s) & $\begin{array}{c}\text { Atividade de } \\
\text { urease }\end{array}$ & $\begin{array}{c}\text { Redução em } \\
\%\end{array}$ \\
\hline 0 segundo & 2,08 & 0 \\
\hline 140 segundos & 0,54 & 74,04 \\
\hline 150 segundos & 0,48 & 0,48 \\
\hline
\end{tabular}

\subsubsection{Solubilidade protéica}

Observou-se uma significativa queda da solubilidade de proteína entre 140 e 150 segundos, conforme a Tabela 4.

Tabela 4. Solubilidade protéica residual (\%) dos grãos aquecidos em microondas

\begin{tabular}{cc}
\hline Tratamentos & $\begin{array}{c}\text { Valores em } \\
\%\end{array}$ \\
\hline 140 segundos & 56,02 \\
\hline 150 segundos & 53,71 \\
\hline
\end{tabular}

O valor experimental adotado, de 150 segundos, foi baseado na opção por um tempo intermediário entre 120 e 180 segundos que garantiria baixa atividade da urease e relativa solubilidade protéica residual. $O$ tempo de 140 segundos garantia um leite com menor grau de tostado e, ainda, atividade ureática reduzida. 


\subsubsection{ADQ}

Realizou-se a seleção de provadores, com o objetivo de se formar uma equipe com elevada acuidade organolética para detectar as diferenças nos tratamentos.

Os efeitos dos tratamentos sobre as características sensoriais são influenciados pelo tempo de exposição no microondas (Wang \& Toledo, 1990) e o uso de bicarbonato do tratamento Illinois em que o sabor do produto se apresenta mais tolerável aos ocidentais (Nelson et al., 1976).

Através da Tabela 5, observa-se diferença estatística apenas nos atributos de consistência visual e organolética do leite de soja submetido aos diferentes tratamentos, sendo que o processo Ilinois recebeu maior nota para esses parâmetros, em relação aos tratamentos realizados com o forno de microondas.

Tabela 5. Médias referentes aos atributos de aparência e textura organolética do leite de soja submetido a diferentes tratamentos.

\begin{tabular}{ccccccc|cc}
\hline \multicolumn{7}{c}{ APARÊNCIA } & \multicolumn{2}{c}{$\begin{array}{c}\text { TEXTURA } \\
\text { ORGANOLÉTICA }\end{array}$} \\
\hline Tratamento & Cor & Brilho & $\begin{array}{c}\text { Caracte } \\
\text { rística }\end{array}$ & $\begin{array}{c}\text { Gordu- } \\
\text { roso }\end{array}$ & $\begin{array}{c}\text { Uniformi } \\
\text { dade }\end{array}$ & $\begin{array}{c}\text { Consis } \\
\text { tência } \\
\text { aparente }\end{array}$ & $\begin{array}{l}\text { Consistência } \\
\text { Organoletica }\end{array}$ & Viscosidade \\
\hline 140 segundos & $3,90 \mathrm{a}$ & $4,41 \mathrm{a}$ & $4,63 \mathrm{a}$ & $2,40 \mathrm{a}$ & $5,25 \mathrm{a}$ & $3,58 \mathrm{~b}$ & $3,14 \mathrm{~b}$ & $2,72 \mathrm{a}$ \\
150 segundos & $4,07 \mathrm{a}$ & $4,62 \mathrm{a}$ & $4,90 \mathrm{a}$ & $2,36 \mathrm{a}$ & $5,36 \mathrm{a}$ & $3,75 \mathrm{~b}$ & $3,23 \mathrm{~b}$ & $2,82 \mathrm{a}$ \\
Illinois & $2,37 \mathrm{a}$ & $4,10 \mathrm{a}$ & $5,11 \mathrm{a}$ & $2,75 \mathrm{a}$ & $5,91 \mathrm{a}$ & $5,05 \mathrm{a}$ & $4,34 \mathrm{a}$ & $3,39 \mathrm{a}$ \\
Valor F & $3,60 \mathrm{~ns}$ & $0,60 \mathrm{~ns}$ & $0,79 \mathrm{~ns}$ & $0,37 \mathrm{~ns}$ & $2,75 \mathrm{~ns}$ & $7,27 *$ & $5,38 *$ & $0,60 \mathrm{~ns}$ \\
C.V\% & $32,03 \%$ & $17,4 \%$ & $12,43 \%$ & $0,69 \%$ & $8,68 \%$ & $16,0 \%$ & $18,02 \%$ & $35,00 \%$ \\
\hline
\end{tabular}

- Médias seguidas da mesma letra não diferem entre si em nível de $5 \%$ de probabilidade. 
Embora os resultados não apresentassem diferença estatística, observa-se que o atributo cor da aparência do leite de soja foi semelhante para os tratamentos 140 e 150 segundos e bem menor para o tratamento Illinois, conforme os parâmetros oferecidos aos provadores (Figura 9). Quanto menor o valor da cor, mais esta se aproxima do branco o que leva a concluir que o processo Illinois conferiu uma coloração mais clara em relação aos demais tratamentos.

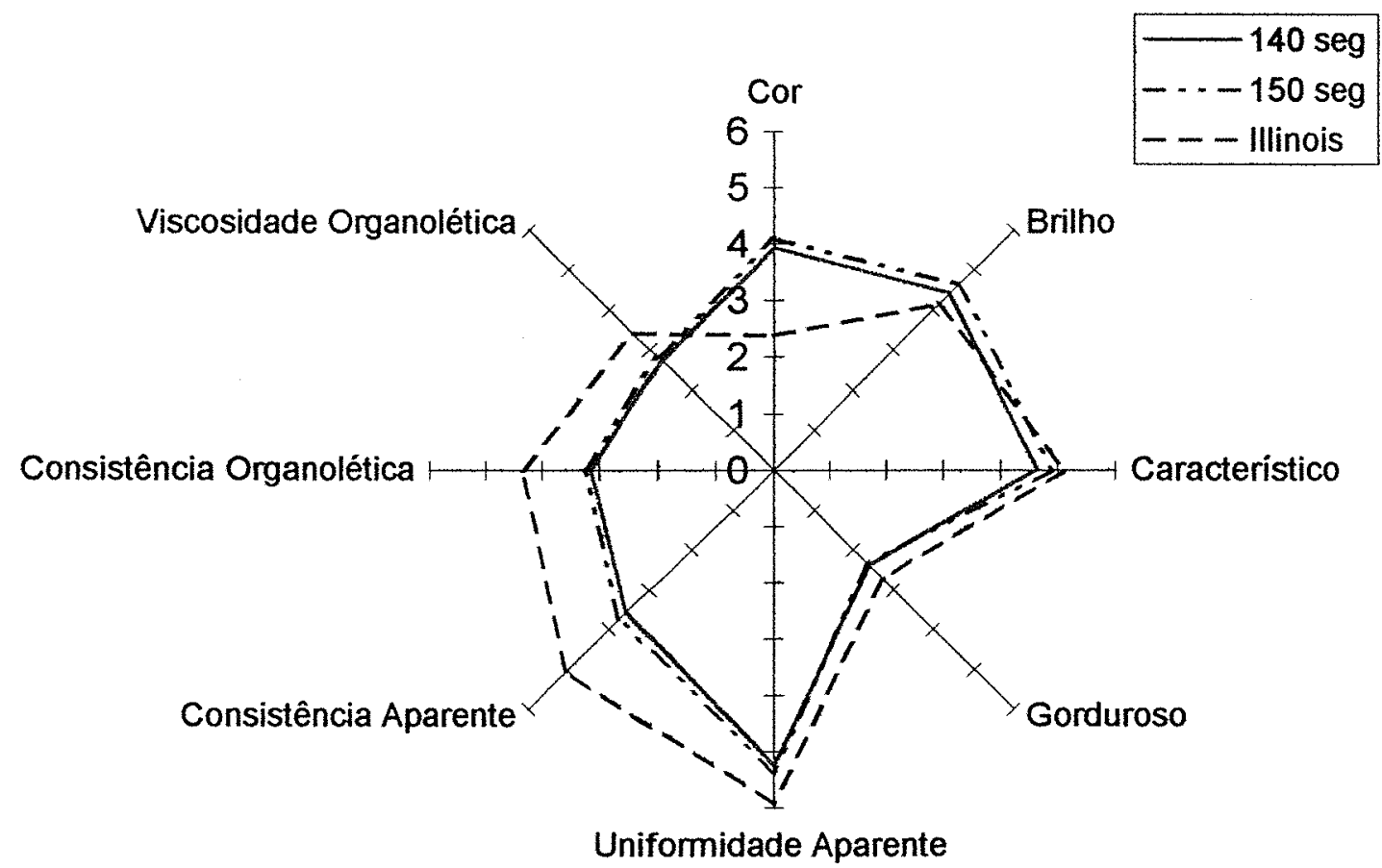

Figura 9 - Atributos de aparência e textura organolética do leite de soja submetido a diferentes tratamentos.

O extrato hidrossolúvel preparado com o tratamento Illinois conferiu uma cor mais clara, sendo portanto, o que mais se diferenciou, porque os grãos apenas foram submetidos ao aquecimento em banho-maria por 30 minutos a uma temperatura de 
$98,8^{\circ} \mathrm{C}$, sendo que este tempo não foi o suficiente para alterar a cor do produto final, como no uso do microondas.

Com relação ao brilho, a mesma tabela mostra que não houve grande diferença entre os três tratamentos. Mesmo assim observa-se que o tratamento Illinois apresentou menor valor para este atributo, e os tratamentos submetidos ao microondas conferiram um brilho ligeiramente maior ao produto.

Os produtos finais foram semelhantes com relação ao atributo característico de leite de soja. $O$ tratamento Illinois apresentou nota um pouco maior em relação ao leite de soja submetido a 140 segundos no microondas. Também para o gorduroso, os dois leites submetidos ao microondas apresentaram o mesmo valor. Somente o tratamento Illinois apresentou uma nota um pouco maior. $O$ mesmo aconteceu com a uniformidade do leite (Figura 10).

Os valores para gorduroso podem ser confirmados através da Tabela 6, na qual o leite de soja extraído pelo processo Illinois, apresenta o maior teor de óleo. Também a uniformidade do leite foi maior nesse extrato hidrossolúvel, talvez devido ao maior teor de proteínas presentes no extrato, em comparação com o leite obtido dos grãos aquecidos em forno de microondas. Uma das possíveis causas para o menor teor protéico seria a maior desnaturação protéica pelo calor das microondas.

Fato importante a ser observado para a consistência aparente, em que os tratamentos 140 e 150 segundos foram bastante semelhantes; porem o tratamento Illinois apresentou, como podemos observar na Tabela 5 e Figura 9, uma característica de leite de soja comercial bastante diferenciada dos demais tratamentos, os quais se assemelham ao mix de soja com suas frutas oferecidas comercialmente.

Quanto aos atributos organoléticos de textura, observa-se que a viscosidade apresentou valores muito próximos para os tratamentos realizados com microondas (Tabela 5 e Figura 9) e os valores se cruzam praticamente no mesmo ponto, sendo que ficou para o tratamento Illinois a maior nota para esse atributo. Para a consistência organolética, podemos observar uma diferença significativa entre os tratamentos, sendo que o tratamento Illinois apresentou um maior valor diante dos tratamentos no microondas com 140 e 150 segundos. 
De maneira geral o tratamento Illinois diferenciou-se bastante dos tratamentos com microondas, observando-se a totalidade dos atributos; sendo a maceração da soja em solução de bicarbonato um pré-tratamento vantajoso para a operação de trituração a quente na produção do leite de soja (Miya, 1975).

Tabela 6. Médias referentes aos atributos de aroma e sabor do leite de soja submetido a diferentes tratamentos.

\begin{tabular}{cc|ccccc}
\hline & AROMA & \multicolumn{5}{|c}{ SABOR } \\
\hline Tratamentos & $\begin{array}{c}\text { Característico } \\
\text { de soja }\end{array}$ & Ranço & Doce & Ácido & Torrado & Amargo \\
\hline 140Segundos & $4,35 \mathrm{a}$ & $2,76 \mathrm{a}$ & $2,35 \mathrm{a}$ & $1,70 \mathrm{a}$ & $3,80 \mathrm{a}$ & $2,77 \mathrm{a}$ \\
150Segundos & $4,35 \mathrm{a}$ & $2,44 \mathrm{a}$ & $2,68 \mathrm{a}$ & $1,81 \mathrm{a}$ & $3,49 \mathrm{a}$ & $2,81 \mathrm{a}$ \\
Illinois & $4,26 \mathrm{a}$ & $2,95 \mathrm{a}$ & $2,71 \mathrm{a}$ & $1,87 \mathrm{a}$ & $1,80 \mathrm{~b}$ & $2,47 \mathrm{a}$ \\
Valor F & $0,02 \mathrm{~ns}$ & $0,26 \mathrm{~ns}$ & $0,26 \mathrm{~ns}$ & $0,13 \mathrm{~ns}$ & $9,65 *$ & 0,38 \\
C.V \% & $15,82 \%$ & $41,83 \%$ & $33,92 \%$ & $30,58 \%$ & $25,52 \%$ & $24,98 \%$ \\
\hline
\end{tabular}

* Médias seguidas da mesma letra não diferem entre si em nível de $5 \%$ de probabilidade

$\mathrm{O}$ aroma e o sabor são os atributos mais estudados da soja, desde que este produto começou a ser utilizado para consumo humano.

No presente estudo, como foi observado na analise sensorial, o aroma característico de leite de soja não apresentou diferença significativa entre os tratamentos, sendo tais conclusões obtidas através da análise estatística e gráfica e estando todos os valores praticamente no meio da escala, nem tanto cru, nem tanto torrado (Tabela 6 e Figura 10).

Com relação ao sabor, apenas o sabor torrado apresentou diferença estatística entre os tratamentos, apresentando notas significativamente maiores para os tratamentos realizados no microondas, em relação ao processo Illinois (Tabela 6 e Figura 10).

O método de utilização do forno de microondas foi uma alternativa para a diminuição do fator cru, característico, diminuindo este fator depreciativo do produto. 
Badenhop \& Hackler (1970) também verificaram que, quando a operação à alta temperatura é precedida de uma maceração durante 2 horas a $50^{\circ} \mathrm{C}$, em solução alcalina, há melhora no sabor, no aroma e na aceitação do leite de soja, não havendo, entretanto, qualquer alteração no seu valor nutritivo. A maceração da soja em solução de bicarbonato é um pré-tratamento vantajoso para a operação de trituração a quente na produção do leite de soja. No entanto são processos demorados e que envolvem o uso de aditivos, enquanto o processo de microondas é um processo naturalmente mais rápido.

Com relação aos demais atributos, não houve diferença estatística (Tabela 6). Para o sabor ácido, principalmente, os valores permaneceram praticamente iguais. Observa-se apenas um ligeiro decréscimo no sabor doce para o tratamento, com 140 segundos no microondas com relação aos demais tratamentos. $O$ sabor amargo também apresentou uma ligeira diferença, obtendo o processo Illinois menor valor para esse atributo, em relação aos demais tratamentos (Figura 10).

Fato interessante observado: o sabor ranço obteve um ligeiro decréscimo para o tratamento com 150 segundos, sendo que o Illinois apresentou maior valor (Figura 10).

A oxidação de lipídeos é um fenômeno muito comum em sementes oleaginosas e em seus produtos. Sabe-se que este fenômeno é facilitado ou catalisado por muitos fatores como luz, oxigênio, calor, umidade, microorganismos, íons metálicos e enzimas, particularmente as lipoxigenases, são os catalisadores mais importantes (St. Angelo et al., 1979). Os tratamentos para inativação das lipoxigenases, envolvem tanto moagem com água quente como o aquecimento a seco, entre outros como o processo Illinois, sendo que o mais usado é o tratamento térmico, por ser razoavelmente eficiente (Kinsella, 1979; Mc Watters \& Holmes, 1979; Aoki et al., 1980; Arai, 1996).

A hidroperoxidação dos ácidos graxos poliinsaturados inicia-se logo após o esmagamento dos grãos, liberando enzima e substrato que até então estavam compartimentalizados. Mesmo após a inativação térmica das enzimas, o processo de degradação oxidativa dos ácidos graxos continua, por meio de reações não enzimáticas (Racknis et al., 1979), mas com uma velocidade bem menor. 


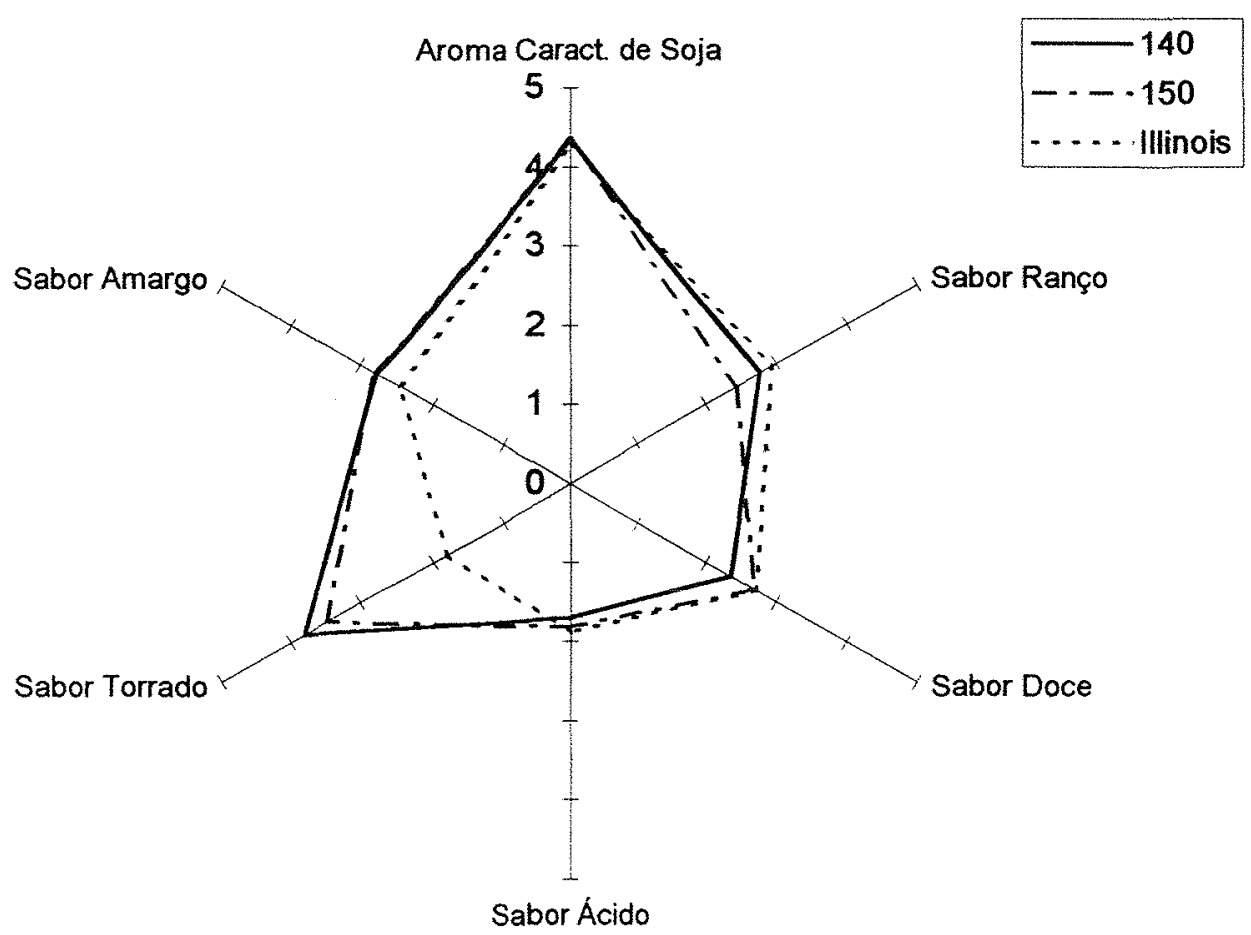

Figura 10 - Atributos de aroma e sabor do leite de soja submetido a diferentes tratamentos.

Conclui-se, portanto, que o processo de aquecimento dos grãos pelo forno de microondas provocou a inativação das enzimas lipoxigenases, em maior escala que o processo Illinois. Evangelista \& Regitano-d'Arce (1999) comprovaram que o emprego do forno de microondas como tratamento térmico inativa ou reduz o potencial oxidativo da soja durante a maceração.

O gosto, aroma e textura, presentes em alimentos e bebidas, mostram mudanças dinâmicas, perceptíveis em intensidade, durante todo o tempo de contato com a mucosa oral (Lee III \& Pang Born, 1986). 


\subsubsection{Teste de aceitabilidade}

Analisando-se estatisticamente os dados obtidos no teste de aceitabilidade (Tabela 7), observa-se que não houve diferença estatística entre os tratamentos, Illinois e microondas.

Embora as notas para o microondas estivessem ligeiramente menores, elas estiveram entre o valor 5 e 6 (indiferente e gostei ligeiramente). Podendo-se concluir que a obtenção de leite, de soja submetido ao tratamento pelo microondas, pode ser uma alternativa de processamento em relação ao processo Illinois.

Tabela 7. Médias de notas do teste de aceitabilidade para o extrato hidrossolúvel de soja submetido a diferentes tratamentos.

\begin{tabular}{cc}
\hline Tratamentos & Médias \\
\hline Illinois & $5,48 \mathrm{a}$ \\
140 segundos & $5,13 \mathrm{a}$ \\
150 segundos & $5.13 \mathrm{a}$ \\
\hline
\end{tabular}

Médias seguidas da mesma letra não diferem entre si em nível de $5 \%$ de probabilidade. 


\section{CONCLUSÕES}

O microondas é uma alternativa atual de tratamento térmico para redução da atividade de fatores antinutricionais.

O tratamento com microondas mostrou-se um método efetivo para a obtenção de leite de soja. A cor mais acentuada, uma menor viscosidade e um sabor de tostado foram encontrados nos leites de soja aquecida em forno de microondas. Ambos os leites preparados com a soja tratada em microondas apresentaram-se sensorialmente aceitáveis e o teste aplicado mostrou-se eficaz ao compará-los com o obtido através do método Illinois.

As alterações observadas nos atributos viscosidade, consistência e uniformidade, podem ser sanadas aumentando_a concentração do soluto. 


\section{REFERÊNCIA BIBLIOGRÁFICA}

AMERICAN ASSOCIATION OF CEREAL CHEMISTS. Aproved methods. 7.ed. St Paul, 1969. 1v.

AMERICAN OIL CHEMISTS' SOCIETY. Official methods and reccomended practices. 2 ed. Champaign, 1983. 1990. 2v.

AMERINE, M. A. ; PANGBORN, R. M; ROESSLER, E. B. Principles of sensory evaluation of food. New York: Academic Press, 1965. p.1-22.

AMINLARI, M. FERRIER, L.K.; NELSON, I. Protein dispersibility of spray-dried whole soybean milk base: effect of processing variables. Journal of Food Science, v. 42, n. 4, p. $985-988,1977$.

AOKI, H.; TANEYAMA, O.; INAMI, M. Emulsifying properties of soy protein: characteristics of $7 \mathrm{~S}$ and $11 \mathrm{~S}$ protein. Journal of Food Science, v.45, n. 3, p. 534, 1980.

ARAI, S; SUZUKI, H; FUJIMAKI, M. et al. Studies on flavor components in soybean. Part 2. Phenolic acids in deffatted soybean flour. Agricultural and Biological Chemistry, v. 60, n.4, p. 364-369, 1966.

ARKOLL, D.B. Inibidores nutricionais da soja. Boletim do Instituto de Tecnologia de Alimentos, v.48, p. 31-49, 1976. 
ASSOCIATION OF OFFICIAL ANALYTICAL CHEMISTS. Official methods of analysis. 15. ed. Washington, 1995. $2 \mathrm{v}$.

BADENHOP, A. F.; HACKLER, L.R. Effects of soaking soybeans in sodium hydroxide solution as pretreatment for soymilk production. Cereal Science Today, v.15, n.3, p.84-88, 1970.

BAKER, E.C.; MUSTAKAS, G.C. Heat inactivation of trypsin inhibitor lipoxygenase and urease in soybeans: effect of acid and base additives. Journal of the American Oil Chemists' Society, v.50, n.5, p. 137-141, 1973.

BAKER, E.C.; RACKIS, J. J. Development of a pilot plant process for the preparation of a soy trypsin inhibitor concentrate. Journal of the American Oil Chemists' Society, v.62, n.1, p.84-87, 1985.

BASENHOP A, F.; WILKENS, W.F. The formation of 1-0-1-octen-ol in soybeans during soaking. Journal of American Oil Chemists' Society, v.46, n.1 p. 179, 1969.

BATTISTI, C. R. Preparo do extrato hidrossolúvel de soja a partir de farinha de soja desengordurada e gordura vegetal emulsificada. Campinas, 1992. Tese (Doutorado)Faculdade de Engenharia de Alimentos, Universidade Estadual de Campinas.

BERNARD, R. L. Genetic improvement of food-type soybeans in the United States and Canadá. In: CONGRESSO BRASILEIRO DE SOJA, 1., Londrina, 1999. Anais. Londrina: CNPSo, 1999. p.93-98.

BORDINGNON, J.R; MANDARINO, J.M.G. Soja: composição química, valor nutricional e sabor. Londrina: Embrapa, 1994, 31p. 
BORHAM, M; SYDER, H. E. Lipoxygenase destruction in whole soybeans by combinations of heating and soaking in ethanol. Journal of Food Science, v.44, n 2, p. $586-590,1979$.

BOURNE, M.C.; ESCUETA, E.E.; BANZON, J. Effect of sodium alkalis and salts on $\mathrm{pH}$ and flavor soymilk. Journal of Food Science, v.41, n.1, p. 62-66, 1976.

BRANCO, N. S. D. C. Aceitabilidade e valor nutricional de uma paçoca elaborada com amendoim, fubá e farinha de soja desengordurada. Lavras, 1988. 90p. Dissertação (M.S.)- Escola Superior de Agricultura de Lavras.

BUCHANAN, B.F.; STEWART, G.F. Identifying solutions to malnutrition in Latin America. Food Technology, v.31, n.9, p.60-70, 1977.

CABRAL, L.C.; SERNA-SILVALDIR, S.O; TINSLEY, A.M. Effects of dehulling, cooking and storage conditions on protein quality and digestibility of soybeans. Archivos Latinoamericanos de Nutrición, v.45, n.1, p.41-45, 1995.

CABRAL, L.C.; WANG, S.H.; ARAUJO, F.B. et al. L.H. Efeito da pressão de homogeneização nas propriedades funcionais do leite de soja em pó. Ciência e Tecnologia dos Alimentos, v.17, n.3, p. 286-290, 1997.

CÂMARA, G.M.S.; GODOY, O.P.; MARCOS FILHO, J. et al. Soja: produção, pré processamento e transformação agroindustrial. São Paulo: Secretaria da Industria, Comércio, Ciência e Tecnologia, 1982. 99p.

CÂMARA, G.M.S.; SEDIYAMA, T.; DOURADO-NETO, D. et al. Influence of photoperiod and air temperature on the growth, flowering and maturation of soybean (Glycine max (L.) Merrill). Sciencia Agricola, v.54, p.149-154, 1997. 
CHAVES, N. Nutrição básica e aplicada. Rio de Janeiro: Guanabara, 1978. 344p.

CHE MAN, Y.B.; WEI, L.S.; NELSON, A.I. Acid inactivation of soybean lipoxygenase with retention of protein solubility. Journal of Food Science, v.54, n. 4, p. $963-967,1989$.

CHIEN, J.T.; SNYDER, H.E. Detection and control of soymilk adstringency. Journal of Food Science, v.48, n.2, p.438-440, 1983.

COPPOCK, J. Soy protein in foods-retrospect and prospect. Journal of the American Oil Chemists' Society, v.51, n, 1, p.59 $-62^{\mathrm{A}}, 1974$.

COSTA DE MELLO, M; SOLORZANO LEMOS, J.L.; CHAVES CABRAL, L. O efeito do descascamento e do choque térmico sobre a acomposição do extrato hidrossolúvel do resíduo insolúvel de soja. Ciência e Tecnologia de Alimentos, v.16, n.3, p.191-195, out./dez. 1996.

COWAN, J.C.; RACKIS, J.J.; WOLF, W.J. Soybean protein flavor components: a review. Journal of American Oil Chemists' Society, v.50, n.7, p. $426^{\mathrm{A}}-435^{\mathrm{A}}$, 1973.

DUTCOSKY, S.D. Análise sensorial de alimentos. Curitiba: Champagnat, 1996. 123p.

EVANGELISTA, C.M.; REGITANO-D'ARCE, M.A.B. Spectrophotometric analysis of the lipid fraction of microwave-heated and soaked soybeans for lipoxygenase inactivation. Grasas y Aceites, v. 50, n. 1, p. 22-25, 1999. 
FERREIRA, V.L.P; SHIROSE, I. Estudo sobre a aromatização do leite de soja destinado a merenda escolar. Boletim do Instituto de Tecnologia de Alimentos, v.44, p.87$102,1976$.

FERREIRA, V.L.P.; SHIROSE, I. O comportamento do leite "Vital" natural quanto aos aspectos Físico-químico-organolépticos. Boletim do Instituto de Tecnologia de Alimentos, n.53, p. 53-68, 1977.

FISHER, R.A.; YATES,F. Tabelas estatísticas para biologia, medicina e agricultura. São Paulo: USP, 1971. 150p.

FOLCH, J.; LEES, M.; SLOANNE STANLEY, G.H. A simple method for the isolation and purification pf lipids from animal tissues. Journal of Biological Chemistry, v. 226 , n. 1, p. $497-509,1957$.

GARRUTTI, R. S. Metodologia na seleção seqüencial e não seqüencial de provadores para análise sensorial de alimentos e bebidas. Campinas, 1976. 211 p. (Tese Doutorado)- Faculdade de Engenharia de Alimentos, Universidade Estadual de Campinas.

GENOVESE, M.I.; LAJOLO, F.M. Atividade inibitória de tripsina em produtos derivados de soja (Glycine max) consumidos no Brasil. Ciência e Tecnologia de Alimentos, v.18, n.3, p.309-312, 1988.

GEROMAZZO, H.; MACORITTO, A.; TORO, M. A. et al. Inativacion de lipoxigenasas e inhibitores de tripsina en un processo de obtencion de soja por molienda directa y alta temperatura. Archivos Latinoamericanos de Nutrición, v. 48, n. 1, p. $52-57,1998$. 
GILLETTE, M. Aplication of descriptive analysis. Journal of Food Protection, v.47, n. 5, p. $403-409,1996$.

GOLBITZ, P. Traditional soyfoods: processing and products. Journal of Nutrition, v.125, suppl. 3, p.570-572, 3, 1995.

GOMES, J .C.; JOSE, I.C.; COELHO, D.T. et al. Extratos hidrossolúveis produzidos de soja sem lipoxigenases. Ciência e Tecnologia dos Alimentos, v.15, n.1, p. 95-103, 1995.

GOMES, J.C.; OLIVEIRA, M.A.S.; OLIVEIRA, M.L. et al. Extrato solúvel de soja: sabor e teor de hexanal. Arquivos de Biologia e Tecnologia, v.32, n.4, p.665-686, 1989.

GORDON, J.F. Alga proteins and the human diet. In: LAWRIE, R.A. Protein as human food. Westport: Avi Publ., 1970. v.1, p.328 - 345.

GORMAN, C. The joy of soy. Times, v.153, n.22, p.67-68, 1999.

HAUMANN, B.F. Soymilk. New processing packing expand markets. Journal of the American Oil Chemist's Society, v.61, n.12, p.1784-1809, 1984.

HELM, E; TROLLE, B. Selection of a taste panel. Walersteins Laboratories Commucations, n.9, p. 1-181, 1946.

HOLMAN, RT; EGWIN, OP; CHISTIE, W.W. Substrate specificity of soybean lipoxidase. The Journal of Chemistry, v.244, n.5, p. 1149-1151, 1969. 
HUHN, S. Efeito do ion cúprico no sabor do "leite de soja". Viçosa, 1977. 42p. Dissertação (M.S)-Universidade Federal de Viçosa.

KINSELLA, J. E. Functional properties of soy proteins. Journal of the American Oil Chemists' Society, v.56, n.3, p.242-258, 1979.

KRAMER, A.; KAHAN, G.; COOPER, D. et al. A non-parametric ranking method for the statistical evaluation of sensory data. Chemical Senses and Flavor, v.1, n.1, p. 121-133, 1974.

KWOK, K.C; NIRANJAN, K Review: effect of thermal processing on soymilk. International Journal of Food Science and Tecnology, v.30, n. 3, p. 263-295, 1995.

LEE III , W.E.; PANG BORN, R.M. Time-intensity: the temporal aspects of sensory perception. Food Tecnology, v.40, n.11, p.71-82, 1986.

LIENER, I. E. Significance for humans of biologically active factors in soybeans and other food legumes. Journal of the American Oil Chemists' Society, v.56, n.3, p.121-129, 1979.

MATSUURA, M.; OBATA, A. Beta glucosidases from soybeans hydrolyze daidizin and genistein. Journal of Food Science, v.58, n.1, p. 144-147, 1983.

MATSUURA, M.; OBATA, A.; FUKUSHIMA, D. Objectionable flavor of soy milk developed during the soaking of soybeans and its control. Journal of Food Science, v. 54, n.3, p.602-605, 1989. 
McWATTERS, KH; HOLMES, M.R. Influence of moist heat on solubility and emulsification properties of soy and peanut flours. Journal of Food Science, v.44, n.3, 774-776, 1979.

MIYA, E. E.; PUPO, L.M.; CHAIB, M.A. et al. Estudo sensorial do sabor do leite de soja. Boletim do Instituto de Tecnologia de Alimentos, v.42, p.43-54, 1975.

MUNOZ, F.P.; FLORES, R.A. Effect of storage time on solubility and color of spraydried soymilk. Journal of Food Protection, v.61, n.2, p.231-234, 1998.

NELSON, A. I.; STEINBERG, M. P.; WEY, L. S. Illinois process for preparation of soymilk. Journal of Food Science, v.51, n.1, p.57-61, 1976.

OH, J.S.; LEE, G.H.; LEE, W.Y. Effect of alkali treatment soybeans on quality of soymilk. Journal of the Korean Society of Food and Nutrition, v. 17, n.2, p.85-94, 1988.

OKUBO, K.; FURUYA BASHI, Y.; TAKA HASHI, K. Improvement of soymilk and tofu process on the behavior of undesirable taste component such as glycosides. Date Food Processing, n.18, p.16-21, 1981.

PAULA, A.C.O. de; CARVALHO Jr, I.C; CABRAL, L.C. et al. Estudo cinético da inativação térmica da lipoxigenase e da insolubilização protéica na soja. Ciência e Tecnologia de Alimentos, v.15, n.3, p.262-267, 1995. 
PINO, L.M.; REGITANO-D'ARCE, M.A.B. Inativação de compostos antinutricionais em microondas. In: CONGRESSO BRASILEIRO DE CIÊNCIA E TECNOLOGIA DE ALIMENTOS, 8., Fortaleza, 2000. Resumos. Campinas: SBCTA, 2000. n.p.

RACKIS, J.J. Significance of soya trypsin inhibitors in nutrition. Journal of the American Oil Chemists' Society, v.58, n.3, p. 495-501, 1981.

RACKINS, J.J.; McGHEE, J.E.; HONIG, D.H. Processing soybeans into foods: selected aspects of nutrition and flavor. Journal of the American Oil Chemists' Society, v.52, p.242 A., 1975.

RACKINS, J.J.; SESSA, D.J.; HONIG, D.H. Flavor problems of vegetable food proteins. Journal of the American Oil Chemists' Society, v.56, n.3, p.262-271, mar. 1979.

RAJKÓ, R.; SZABÓ, G.; VIDAL-VALVERDE, C. et al. Designed experiments for reducing antinutritive agents in soybean by microwave energy. Journal of Agricultural and Food Chemistry, v.45, n.9, p.3565-3569, 1997.

REGITANO-D'ARCE, M.A.B. Tecnologia da transformação. In: CÂMARA, G.M.S.; GODOY, O.P.; MARCOS FILHO, J. et. al. Soja; produção, pré processamento e transformação agroindustrial. São Paulo: Secretaria da Industria, Comércio, Ciência e Tecnologia; FEALQ, 1982. p.53-99. (Série Extensão Agroindustrial, 7).

SANTOS, C. J. C. Teor de isoflavonas e atividade de beta glicosidase em grãos de soja (Glycine max (L.) Merril). Lavras, 1993. 51p. Dissertação (M.S.) - Escola Superior de Agricultura de Lavras.

SAS, INSTITUTE. SAS user's guide: statistic. 6.ed. Cary, 1988, 584p. 
SAVAGE, WD.; WEI, L.S.; SUTHERLAND, J.W. et al. Biologically active components inactivation and protein insolubilization during heat processing of soybean. Journal of Food Science, v.60, n.1, p.164-168, 180, 1995.

SILVA JUNIOR, S.I. da. A. avaliação da qualidade nutricional do leite de soja e do leite integral em pó ensaio experimental e discussão metodológica. Alimentação e Nutrição, v.8, p.105-120, 1997.

SJÖSTRÖM, LB. Correlation of objective-subjective methods as applied in the food field. In: CORRELATION OF SUBJECTIVE-OBJECTIVE METHODS IN THE STUDY OF ODORS AND TASTE ANNUAL MEETING, 7., Boston, 1967. Philadelphia:ASTM, 1968. p. 3-16.

SOLORZANO, L.; COSTA DE MELLO, J.L.; CABRAL, L.C. Estudo da solubilidade das proteínas de extratos hidrossolúveis de soja em pó. Ciência e Tecnologia de Alimentos, v.17, n.3, p. 337-340, 1997.

SONG, Y.; LOVE, M. H.; MURPHY, P. Subcelular localization of lipoxygenase 1 and 2 in germinating soybean seeds and seedlings. Journal of the American Oil Chemists' Society, v.67, n.12, p.961-965, 1990.

St ANGELO, A.J.; KUCK, J.C.; ORY, R.L. Role of lipoxygenase and lipid oxidation in quality of oilseeds. Journal of Agricultural and Food Chemistry, v.27, n.2, p.229-234, 1979.

STONE, H. J.; SIDÉL, S.; OLIVER, A. et al. Sensory evaluation by quantitative descreptive analysis. Food Technology, v.28, n.11, p.24-34, 1974. 
TANG S.G.; ONO,T.; MIKAMI, M. Interaction between protein and lipid in soybean milk at elevated temperature. Journal of Agricultural and Food Chemistry, v.45, n. 12 p. $4601-4605,1997$.

TEIXEIRA, R.C.; SEDIYANA, T.; ANDRADE, M.A.S. et al. Considerações sobre a soja na alimentação humana. In: UNIVERSIDADE FEDERAL DE VIÇOSA. Dia de campo sobre a cultura da soja. Viçosa, 1995. p. 22-23. (Boletim Técnico).

THANANUNKUL, D.; TANAKA, M.; CHICHESTES, C .O. et al. Degradation of raffinose and stachiose in soybean milk by alfa galactosidase from Mortierella vinacea. Entrapment of alfa galactosidase withn polyacrylamide gel. Journal of Food Science, v.41, n. 3, p.173-175, 1976.

VIEIRA, C. R.; CABRAL, L.C.; PAULA, A.C.R. Caracterização fisica e tecnológica de seis cultivares de soja plantadas no Brasil. Ciência e Tecnologia de Alimentos, v.17, n.3, p.291-294. 1997.

WANG, H.L.; SWAIN, E.W.; HESSELTINE,C.W. et al. Hidration of whole soybeans affects solids losses and cooking quality. Journal of Food Science, v.44, n.5, p.1510-1513, 1979.

WANG, S.H.; TOLEDO M.C.F. Evaluacion del valor nutricional de leches de soya preparadas a partir de granos de soya tratados com microondas. Archivos Latinoamericanos de Nutrición, v.40, n.4, p.572-587, 1990.

WHITAKER, J.R. Principles of enzimology for the food sciences, New York: Dekker, 1972. 499p. 
WILKENS, W.F; MATTICK, L.R.; HAND, D.B. Effect of processing method on oxidative off-flavors of soybean milk. Food Tecnology, v.21, n.12, p.86-89, 1967.

WOLF, W.J. Lipoxigenase and flavor of soybean protein products. Journal of Agricultural and Food Chemistry, v.23, n.2, p. 136-141, 1975.

YOSHIDA, H.; KAJIMOTO, G. Effects of microwave treatment on the trypsin inhibitor and molecular species of tryglicerides in soybeans. Journal of Food Science, v.53, n.6, p.1756-1760, 1988. 